\title{
Connections and Performance in Bankers' Turnover: Better Wed over the Mixen than over the Moor
}

\author{
ERICH BATTISTIN \\ ClARA GRAZIANO \\ BRUNO M. PARIGI
}

CESIFO WORKING PAPER NO. 2439

CATEGORY 4: LABOUR MARKETS

OCTOBER 2008

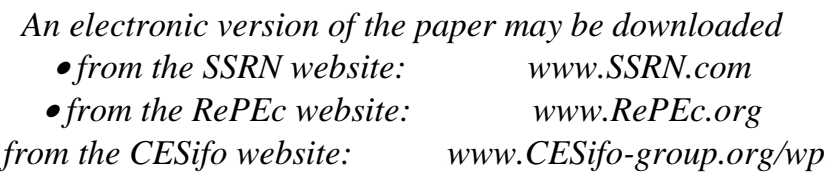




\title{
Connections and Performance in Bankers' Turnover: Better Wed over the Mixen than over the Moor
}

\begin{abstract}
In this paper we study top executive turnover in Italian Banks over the period 1993-2001. We relate the probability of survival of top executives (Presidents, CEOs and General Managers) to bank performance and the manager's local connections, controlling for (observable and unobservable) bank and manager characteristics by exploiting longitudinal information on bank-manager appointments. We measure the extent? of managers' local connections by the distance between the province of the bank's headquarters and the manager's province of birth. We show that top managers tend to be local in the sense that the distribution of this distance is heavily skewed towards zero. On the basis of this evidence, we address two questions. First, we investigate whether connections affect the duration of the appointment at the bank. Second, we ask whether connections entrench managers at the expense of the bank's performance. We find that connections generally increase the probabilities of managers surviving at their banks, and that the positive effect of performance on tenure (as amply documented by the executive turnover literature) disappears once connections are taken into account. On the other hand, we provide evidence against the hypothesis that managerial connections contain information valuable for enhancing a bank's performance. In particular, we find that highly connected boards cause the shorter survival of banks, and that those who benefit from connections are top managers themselves (mostly Presidents and General Managers). This suggests that connections may be collusion devices with which to maintain and share rents.
\end{abstract}

JEL Code: J40, J63, G21, G34.

Keywords: connections, executive turnover, commercial and cooperative banks.

\author{
Erich Battistin \\ University of Padova \\ erich.battistin@unipd.it \\ Bruno M. Parigi \\ University of Padova \\ brunomaria.parigi@unipd.it
}

\author{
Clara Graziano \\ Department of Economics \\ University of Udine \\ Via Romadini 30 \\ Italy - 33100 Udine \\ clara.graziano@uniud.it
}

This version: October 14, 2008

The authors wish to thank the Italian Ministry of University and Research for financial support and the Padova Chamber of Commerce for allowing access to their data. The paper has benefited from various comments by audiences at the EEA Conference 2007, the EARIE Conference 2007, the ASSET Conference 2007, and from helpful discussions with Cinzia Baldan, Mariassunta Giannetti, Adriano Paggiaro, Franco Peracchi, Alberto Pozzolo, and Enrico Rettore. Thomas Ciatto, Roberto Piazza, Enrico Pizzolato and Flaviano Vrech provided valuable research assistance. The usual disclaimer applies. 


\section{Introduction}

In this paper we study the turnover of top executives of Italian banks in relation to a bank's performance and the local connections of its manager, controlling for observable and unobservable bank and manager characteristics by exploiting longitudinal information on bank-manager appointments.

It has been widely documented that connections and social networks play a crucial role in labor outcomes by affecting the circulation of information about employment opportunities, turnover rates, chances of obtaining a higher salary, and labor market participation (see for example Goyal 2007, and the survey by Ioannides and Loury 2004). Connections and network effects are particularly important for positions and industries where what matters is information about the person's quality and the information that s/he may have acquired about the business. Such effects are of substantial importance for top managers.

Banking is an industry of particular interest when investigating the above issues because it is information-intensive. The literature shows that relationship lending is important chiefly for small and medium-sized firms where "soft" borrower-specific information matters (Bhattacharya and Chiesa 1995, Petersen and Rajan 1994, Degryse and Ongena 2005). One dimension of relationship banking is "distance", which is measured in various ways: distance between the bank's headquarters and the borrower (Casolaro and Mistrulli 2007), between the lending branch and its customers (Petersen and Rajan 2002, Degryse and Ongena 2005, Carling and Lundberg 2005), and between hierarchical layers in the bank (Stein 2002).

The Italian banking industry offers a good environment in which to study these issues for a number of reasons. First, in the absence of a well-developed capital market, banks provide the largest share of outside funds, in particular to small and medium-sized firms. Second, the Italian population is local: according to the 2001 Census, $86.23 \%$ of Italians live in their region of birth, and $46.47 \%$ in their province of birth. ${ }^{1}$ This suggests that the bulk of the Italian population stays very close to their birthplaces over time, with the potential of developing local connections. The importance of these connections for labor market outcomes has been documented by Cingano and Rosolia (2007), who show that around $70 \%$ of the manufacturing workers in their sample worked in their province of birth, and that employed contacts significantly increased their probability of reemployment.

Third, the Italian banking industry has undergone major changes which have simultaneously increased the importance of market forces and of local forces. Before 1990 the Italian banking industry was heavily protected by banking legislation enacted during the Depression years in order

\footnotetext{
${ }^{1}$ A province is administratively similar to a U.S. county.
} 
to enhance bank stability both through severe restrictions on competition (Guiso et al. 2006), and through government ownership of banks. In the 1990s several pieces of legislation allowed banks formerly chartered as public institutions to be converted into joint stock companies, and this paved the way to their privatization and to an increase in competition. However, the controlling blocks of many newly-privatized banks were allocated to Bank Foundations, which were accountable only to the local community and had close ties with particular cities. This increased the importance of local, as opposed to nationwide, factors in bank governance. As a result of the sweeping regulatory changes of the 1990s, technological innovations, and the prospects of European monetary unification, between 1990 and 2001552 mergers and acquisitions between banks took place in Italy to involve approximately $50 \%$ of deposits, while in the same period the number of banks declined from 1061 to 769 (Panetta 2004).

In an ideal world, banks would like to hire, promote, and retain the most talented top managers. Hence they would want to draw on the largest possible pool of talent, and this would give rise to geographically diverse top managements. However, a number of frictions may generate a different kind of behaviour. There are two competing hypotheses as to why banks may prefer to hire local managers even after they have conducted a search in a geographically diversified pool.

The first explanation relies on the fact that a local banker may have a better knowledge of the local economy and of the local business community, and this information can be used for the bank's benefit. Evidence of this is provided by the above-mentioned literature on relationship lending. Further evidence that social networks and connections facilitate information flows is furnished by the mutual fund industry. Mutual fund managers invest more in firms within their network and they earn higher returns (Cohen et al. 2007). Analysts with school ties to a company's senior officers outperform on their stock recommendations (Frazzini et al. 2008). Similarly, geographically proximate U.S. analysts possess an information advantage which translates into better performance (Malloy 2003). More generally, social capital has a local dimension, and it matters in financial development (Guiso et al. 2005). Political connections, too, may help a bank's performance. In a cross-country study, Faccio (2006) has analyzed the effects of having politically connected CEOs and directors on the board, and shown the widespread presence of politicallyconnected controlling shareholders and/or top officers.

An alternative and less benign hypothesis is that banks have the power to distribute large amounts of benefits: monetary, private and political. This idea has been put forward by several studies in the literature. The benefits from belonging to the networks of the French business élite (alumni of the Grandes Ecoles) have been documented by Nguyen-Dang (2006). He finds that, when the $\mathrm{CEO}$ and some board members belong to the same alumni network, turnover-performance 
sensitivity is lower, and if the connected CEO is ousted s/he is more likely to find a new job. Kramarz and Thesmar (2006) provide evidence that politically connected French CEOs determine the composition of the board of the companies that they run, and this helps them retain their jobs after poor performance. Similarly, Sapienza (2004) has analysed political influence on state-owned Italian banks, finding that they provide support for the winning parties in the form of subsidized loans. The interplay between connections and individual and firm performance has been studied by Bandiera et al. (2007) to evaluate whether the existence of social connections within a managers/workers organization is beneficial to the firm's overall performance. They find that only when managers have high-powered incentives do they favour high-ability workers regardless of their connections; otherwise they favour connected workers regardless of their ability.

To reinforce the latter interpretation, the power of banks to distribute monetary, private and political benefits is based on collusion amongst their top managers, and it is reasonable to expect that collusion is more likely to be established and maintained among members of the same network. For example, Subrahmanyam (2008) shows that members of board of directors are not effective monitors of the CEO because they are likely to belong to the CEO's social network and they want to preserve their "social capital". Local top managers are more likely to belong to same network and therefore to collude with each other than non-local managers. Hence top managers may tend to be local even in banks with geographically spread operations. It is worth noting that, in Italy, the local dimension of bankers' power has been reinforced by the creation of Bank Foundations, which, as mentioned, have close ties with particular cities.

The connections of the executive, the performance of the institutions, M\&As, and regulatory changes jointly affect the turnover of bankers. Turnover is a significant ingredient of governance: a negative relationship between turnover and performance is indicative of good governance. In what follows we will focus on turnover of Italian bankers in order to shed light on two related issues. First we investigate the relative importance of connections and performance as determinants of managerial turnover and of the resulting tenure at a bank. Second, we test the competing hypotheses that connections have an information value that helps bank's performance, or that connections foster collusion among top managers and affect performance negatively.

To measure the strength of a manager's connections we use information on the distance between his/her province of birth and the province where the bank is headquartered. According to this measure of connection, the greater the distance, the fewer the manager's connections. Although, as said, the banking literature has developed various measures of "distance", to the best of our knowledge this is the first time that social and economic connections are measured in this 
way. Because of the aforementioned low mobility of the Italian population, we believe that distance is a measure of connections suitable for the problem at hand.

We integrated information from different sources in order to obtain data on the universe of Italian banks for the period 1993-2001, as well as on a rich set of characteristics of their Presidents, CEOs and General Managers. This enabled us to study the job tenure of top managers by exploiting matched bank/manager data for the period considered. In particular, for each bank we were able to determine the number of top managers in place, and to follow them throughout their careers at the bank. We were also able to track the mobility of the top managers across banks by uniquely identifying individuals employed in the three positions considered in the banking sector during the period considered.

The profound regulatory changes that took place over the period considered could in principle be exploited as an exogenous source of variation. However, in practice it is very difficult to trace the effects of this process on managerial turnover, because it resulted from overlapping waves of changes whose implementation was largely spread over time. For this reason, in what follows our identification strategy will not rely on instrumental variable methods; rather, it will exploit the availability of panel data.

Our empirical analysis consists of the following steps. First, we model the probability of turnover at each time period conditional on the tenure of managers at the bank, thus studying the determinants of the dynamics that lead to exit from the position. We let such probability depend upon a large set of observable characteristics as well as on bank/?manager unobservables which were match-specific. If the risk of turnover at each time period is known, the survival probabilities of managers at banks can be estimated allowing for differential effects of connections on their shape and level. This approach allows us to study whether survival probabilities differ on average across bank types or whether they vary with manager characteristics, and also to examine how the dynamics that generate turnover are affected by such characteristics (and, in particular, by connections). Second, we used longitudinal information on managers at banks in order to evaluate the causal effect of connections on bank performance and bank survival. To this end we control for unobserved bank heterogeneity by means of fixed effect regressions and use mobility across banks as an additional source of variability to control for unobserved heterogeneity of managers.

To preview our main results, we find that local connections matter in various ways for Italian bankers. Bankers are local in the sense that the distribution of the variable 'distance' is heavily skewed towards zero. This holds true for all the positions considered and regardless of the bank's degree of geographical concentration: that is, the finding applies to banks that operate both locally and nationwide. Moreover, banks with more geographically concentrated operations are 
more likely to employ local managers in the three positions considered. In regard to the probability of remaining in the job, having more connections increases survival probabilities for Presidents and General Managers by around $25 \%$ and $20 \%$ on average, respectively, but has no effect on the tenure of CEOs. Furthermore, we find that, for all the positions considered, tenure at a bank does not depend on performance - as measured either by ROE or by EBITDA over Total Assets - once connections have been accounted for. As for the two competing hypotheses on the role of connections, our results can be summarised as follows. First, we find evidence of negative returns to connections in more geographically concentrated banks, that is, in banks where connections are most likely to play an important role. Second, we find that connected boards affect bank survival negatively. Overall, these findings are fully consistent with the hypothesis that connections are collusion devices used to share and maintain rents, but not with the hypothesis that connections convey information that helps a bank's performance.

The rest of the paper is organized as follows. Section 2 presents the main characteristics of the information available, while descriptive statistics are presented in Section 3. In Section 4 we illustrate the empirical strategy used to investigate the causal effects of connections on the tenure of top managers as well as on bank performance. The results are presented and discussed in Section 5, while Section 6 concludes.

\section{Data}

The aim of this section is to describe the sources of information exploited throughout the analysis. First, we will describe how we combined data from complementary administrative archives to obtain information on both banks and managers for the time period considered. We will then present the bank and manager characteristics that are necessary for our specification.

\subsection{Data sources}

We made use of data from three complementary sources: a dataset that contains mainly bank-level information (Bilbank), and two datasets on the characteristics of managers appointed at banks (Annuario ABI and Telemaco). Bilbank is a data source managed by the Italian Bank Association (ABI) which provides bank-level information on the balance sheets, group affiliations and major operations (like M\&As) of all the banks operating in Italy. Annuario ABI (ABI Yearbook) provides information on the identities and the level of education of CEOs, Presidents and other members of the boards of directors of Italian banks. Finally, the Italian Chamber of Commerce's Telemaco data bank provides information about bank managers' dates and places of 
birth. In addition to these sources, information on the number of branches per province was gathered through the Bank of Italy.

Our reference population comprises all banks operating in Italy during the period 19932001. It thus covering a time span in which the sweeping regulatory reforms that took place in Italy during the 1990s displayed their major effects. Longitudinal information on each bank was obtained from Bilbank by following banks over the time window considered. Bank information such as balance sheets was available on a yearly basis, so that a panel of banks for up to nine years could be defined. We were able to obtain information on Presidents, CEOs, and General Managers for each bank and in each year, and this information was used to merge managers' characteristics into our data by using Annuario ABI and Telemaco. Consequently, our final dataset consisted of matched bank/?manager data with 8,371 observations referring to 739 banks and 1736 managers. Most importantly, this enabled us to follow managers through their different appointments at banks over the period considered.

\subsubsection{Bank characteristics}

In what follows we will describe the information on banks obtained from the combination of data sources. The list of variables available for banks is reported in the bottom panel of Table 1 .

Since our reference population comprises several types of banks (Commercial, Savings, Mutual, Cooperative and Rural), we decided to classify banks into two main groups according to their voting mechanisms. ${ }^{2}$ The first group includes banks whose voting mechanisms is based on the number of shares owned, i.e. Commercial and Saving banks converted into joint stock companies. The second group comprises Mutual, Rural and Cooperative banks. Mutual Banks and Rural and Cooperative Banks are all cooperatives and their governance establishes a per capita voting mechanism which gives each member of the coop the same voting rights regardless of the shares owned. This shields these banks against hostile takeovers, and entrenches their top managers more than those of Commercial banks, and Saving banks. The fact that the members of these cooperatives are often employees of the bank themselves as well as being local residents, and the legal restrictions that until 1986 prevented these banks from branching outside a narrow geographical area, make them essentially local banks (see Guiso et al. 2006). To reinforce this notion, it is worth pointing out that in some instances the bank charter establishes that a minimum proportion of the directors must be drawn from the local community and that Rural and Cooperative banks must

\footnotetext{
${ }^{2}$ Although these types had different origins reflecting their initial specializations, the distinction among them became blurred over time with the gradual repeal of the 1936 Italian banking law, so that they eventually came to perform the same functions.
} 
make at least $50 \%$ of their loans to their members and reinvest at least $70 \%$ of their profits in the local community.

For each bank we know whether the bank is independent or affiliated to a Bank Holding Company (BHC), whether it is the head of a BHC and whether it is listed on the Italian stock exchange. In the period considered, only $20 \%$ of Commercial and Saving banks and 2\% of Mutual, Cooperative, and Rural banks were listed on the Italian stock exchange. We also know the province and city of in which the bank's headquarters is located. Using information on the number of branches per province, we constructed an index of geographic concentration of bank operations defined as the fraction of branches in the province of the bank's headquarters over the total number of branches of that bank (thus implying that if this index assume value one, the bank operates only in one province). We measured bank size by the value of total assets. Only for listed banks we have information on price/earnings ratio, and on gross dividend per share.

We distinguished between episodes of mergers and acquisitions that took place over the period considered. Each bank operating in Italy is identified by its ABI code. We say that a merger takes place if the ABI code of the target bank disappears after the merger. In this case President, CEO and General Managers of the target bank cease. We say that an acquisition takes place if the $\mathrm{ABI}$ code of the target bank remains after the acquisition. In this case the target bank maintains the board of directors, although individual directors and top managers not on the board may change. ${ }^{3}$ Owing to the numerous M\&A episodes that took place in the sample period (net of newlyestablished banks), the number of ABI codes (indicator of the number of banks) in our sample decreased from 619 in 1993 to 566 in 2001. As a result, the fraction of independent banks in our sample diminished. We were also able to distinguish between banks that have changed their position within a $\mathrm{BHC}$ whilst maintaining their $\mathrm{ABI}$ code, and banks formerly in a BHC which became independent.

Finally, as very few Italian banks are listed, we decided to focus only on accounting-based measures of performance, despite the well-known drawback that they may be manipulated by the executives themselves. The performance indicators that we considered are the return on equity (ROE) and earnings before interest, taxes, depreciation and amortization (EBITDA) divided by total assets. We chose not to use information about non-performing loans, because these may be distorted by the ample discretionary power on the timing of their disclosure. Furthermore, the abovementioned profit-reinvestment policy of Mutual and Rural banks often furnishes additional funding for the weakest firms, thus depriving non-performing loans of a useful signalling role. To overcome

\footnotetext{
${ }^{3}$ See Focarelli et al. (2002) for a similar definition.
} 
the problems arising from the possibility that the accounting performance measure might be manipulated, we also used bank survival as a crude measure of bank performance.

[Insert Table 1 about here]

\subsubsection{Top manager's characteristics}

The list of manager characteristics that we were able to reconstruct is reported in the top panel of Table 1. We have information on the following managerial characteristics: age, education, place of birth, and whether the manager had received an honorary title. Education is our main measure of manager's human capital. In Italy it is quite common for honorary titles to be bestowed on people that have distinguished themselves in service to the country, their community, or their business. The importance of honorary titles as indicative of connections has also been suggested by Guiso et al. (2005). ${ }^{4}$

Throughout this paper we will measure the strength of a bank manager's local connections by the distance between his/her province of birth and the province where the bank is headquartered. Given the relatively low mobility of the Italian population, living in the same area where one was born is still common in Italy, and over time it enables individuals to develop important networks of connections. More specifically, distance is obtained by calculating the spherical distance (i.e. corrected for the earth surface curvature) measured in kilometres between the geographical coordinates (in degrees, minutes, and seconds) of the province of the bank's headquarters and the manager's province of birth. We interpret this variable in the sense that the greater the distance, the fewer the manager's connections.

Only limited information on a manager's appointment at the bank was available. In particular, we were only able to reconstruct the manager's position at the bank and (but not in all cases) the starting date of the appointment. The number of positions considered varies according to the type of bank. Most Commercial and Saving banks have a President with a supervisory role, a CEO with an executive role, and a General Manager. In Mutual, Rural and Cooperative banks, instead, the President often also performs the functions of the CEO, so that the latter position is observed only in very few banks of this type.

Our data provide information about the top bankers at the survey time of each year (June 30). ${ }^{5}$ Using this information we were able to follow managers throughout their careers at their banks over the period 1993-2001; and in each year we defined their job tenure as the number of years

\footnotetext{
${ }^{4}$ In the past it was much more common for bankers to hold honorary titles: for example, Guiso et al. (2005) show that $65 \%$ of Saving banks' directors in 1933 had the title of "cavaliere" ("knight").

${ }^{5}$ Thus we have no information on spells on boards completed in between two consecutive survey years. Whilst this may mean that turnover is underestimated, anecdotal evidence indicates that instances of top executives resigning or being fired after only a few months in the job are rare.
} 
spent in the same position. Unfortunately, our data do not allow us to identify the causes of the turnover of managers at a bank, e.g. forced resignation, voluntary quit, death, illness or retirement. Furthermore, we have no information on whether the bank charter specifies a mandatory retirement age.

Job durations can be right censored because we don't have information about board memberships after 2001 (our last survey year). Note that left censored job durations may appear in the data, because for 1993 we observe the stock of managers in place in the universe of the banks operating in Italy, but we don't know when their position at the bank had started. We partially overcame this problem by exploiting additional information on the starting dates of jobs which we were able to retrieve for listed banks. However, the number of left-censored observations remained non-negligible. In particular, left censoring appears to be more problematic for managers in Mutual, Rural and Cooperative banks, where around 54\% of managers are left censored compared to $34 \%$ of managers in Commercial and Savings banks. Presidents are on average more likely to have leftcensored durations (49\%) than General Managers and CEOs (around 35\%). We find that left censoring is strongly associated with being employed in banks that are geographically more concentrated. This reflects in the lower mobility of managers at Mutual, Rural and Cooperative banks compared to Commercial and Savings banks. For example, in the former case around $37 \%$ of Presidents who were observed on the board in 1993 remain in the same position throughout the time window covered by our analysis. For Commercial and Savings banks this number decreases to $5 \%$. However, the difference between these figures is less pronounced if we look at General Managers and CEOs. Moreover, we find that the propensity to have left-censored appointments varies greatly along several bank and manager dimensions, and in particular that is positively associated with the age of the manager, connections and with having a honorary title.

\section{Descriptive analysis}

The aim of this section is to discuss the sample selection criteria adopted that led to the final sample used in the analysis, as well as to provide descriptive statistics about bank and manager characteristics. Here and in what follows the observations will refer to matched bank/manager data: that is, for each bank over the window considered we have repeated observations over time for the same manager, and observations for all the top managers appointed in each year.

We applied the following minor selection criteria to obtain the sample used for the empirical analysis. First, we excluded observations referring to managers for whom we were unable to retrieve information about their place of birth, and thus the measure of connection (this number proved to be negligible). Second, since almost all Mutual, Rural and Cooperative banks did not 
have a CEO (as discussed in the previous section), for this group of banks we limited observations only to Presidents and General Managers. Again, this selection proved to be not binding. Finally, we decided to consider the top executive turnover resulting from acquisitions but not from mergers, because after a merger turnover occurs with probability one by definition. As a result of these steps, our final sample consists of 8,371 observations referred to 739 banks and 1736 managers. ${ }^{6}$

Table 2 reports summary statistics for bank characteristics by bank type. Unlike Commercial and Saving banks, Mutual, Rural and Cooperative banks tend not to be headquartered in a provincial capital, tend to be independent, and are less likely to be listed on the Italian Stock Exchange or to be heads of a BHC. As expected, Commercial and Saving banks are less likely to have their branches concentrated in the province where the bank is headquartered: on average $66 \%$ of their branches are in the headquarter province vis-à-vis $92 \%$ for the other group of banks.

[Insert Table 2 about here]

The distribution of ROE across bank types appears markedly different, with Commercial and Saving banks presenting smaller values on average. In fact, we found that the same result holds at all percentiles of the ROE distribution, thus producing a distribution for Mutual, Rural and Cooperative banks skewed towards larger values of this indicator. On the other hand, the distribution of EBITDA over Total Assets does not vary across bank types.

Table 3 reports summary statistics for manager characteristics. Presidents are on average older and better educated than managers in the other positions. Moreover, they are more likely than the others to have honorary titles. Mutual, Cooperatives and Rural banks have the lowest fraction of managers with college degree.

\section{[Insert Table 3 about here]}

Table 4 reports percentiles of the distribution of the distance between the province of the bank's headquarters and the manager's province of birth by bank type and position. This is the key variable that we use to study the intensity of connections of managers. The distribution is markedly skewed towards zero for both types of banks, though to a lower extent for Commercial and Saving banks. For all positions at a bank, at least $25 \%$ of managers have values for distance equal to zero. In Mutual, Cooperatives and Rural banks the percentage increases to $75 \%$ for Presidents and to 50\% for General Managers. Overall, managers in Mutual, Cooperative and Rural banks are more local than managers in Commercial and saving banks. Consistently with this evidence, we found that the proportion of managers born abroad (which corresponds to just over $1 \%$ of our sample) is concentrated in Commercial and Saving banks and in the CEO position. Presidents are on average the most connected and CEOs the least connected.

\footnotetext{
${ }^{6}$ Missing values were handled by adding "missing dummies" to the regressions considered in the following sections.
} 
[Insert Table 4 about here]

Table 5 sheds more light on the relationship between our measure of connections and other observable characteristics of the manager. We found that the level of connections varies with education and position. In particular, for each position, better educated managers are less connected than are lower educated managers, and this difference is statistically significant at the conventional levels. The fact that more connected managers are also less educated is not per se an indication that they are less valuable to the bank. If connections affect bank performance positively, then connections and education can be seen as substitute dimensions of human capital. Furthermore, if education signals unobservable skills, and if being local provides better information about those skills, then being local may be a sorting device alternative to education. Moreover, we find that Presidents and CEOs with honorary titles are on average more connected. This is consistent both with the notion that the receivers of the title have honoured their local communities, as well as with the notion that they perform valuable lobbying services in the local communities.

[Insert Table 5 about here]

As far as turnover of managers is concerned, we find that its occurrence remains relatively stable over the sample period but with markedly different levels for the three positions considered. On average, the yearly rate of turnover is $9 \%, 16 \%$ and $15 \%$ for Presidents, CEOs and General Managers, respectively, with higher values in Commercial and Saving banks. To establish a link with the executive turnover literature, we modelled the occurrence of turnover as a function of bank and manager characteristics. The results from a simple probit regression show that an increase in performance negatively affects the probability of turnover regardless of the measure of performance considered. Similar conclusions have been drawn for example by Brunello et al. (2003), who showed that for the CEOs of Italian non-financial listed firms the performance/turnover relationship is negative when the CEO is not the controlling shareholder; by Barro and Barro (1990), who examined U.S. commercial banks, finding a negative relationship between CEOs turnover and stock returns; and by Houston and James (1993), who found that the frequency of manager turnover among poorly-performing U.S. commercial banks was about the same as that in poorly-performing non-banks. The overall picture that emerges from our data is thus very much in line with the one documented by other studies on top executive turnover. However, as we mentioned above, this literature does not take account of the impact that the manager's connections may have on turnover, which is one of the main motivations of the present study.

Another piece of information worth considering is how job tenure relates to turnover. For descriptive purposes, in Table 6 we report the average job duration for the three positions considered, restricting the sample to observations that are not left censored and accounting for right 
censoring by fitting a parametric lognormal model to the data. The differences across positions and bank types are clear-cut. Presidents on average stay longer at banks than managers in the other positions (almost three times longer than General Managers), and this holds particularly true for Mutual, Cooperatives and Rural banks, where Presidents have an average tenure of 10 years compared to 7 years in Commercial and Saving banks (these differences are statistically significant at the conventional level).

\section{[Insert Table 6 about here]}

Table 7 studies the relationship between tenure at a bank and our measure of connection by reporting Kaplan-Meyer estimates of the survival functions for two groups of managers. Very pragmatically, given the evidence provided in Table 4, we decided to estimate separate models for local managers, which we defined as those whose measure of distance is zero, and for managers with positive values of the variable 'distance'. In presenting our results here and in what follows, we shall refer to these two groups as "more connected" and "less connected" managers, respectively. We find that more connected Presidents and General Managers have higher survival probabilities than do their less connected peers, and that the difference for CEOs is not statistically significant. To conclude, although this evidence does not account for unobserved heterogeneity across managers and banks, it points to connections as a key determinant of turnover and tenure (as the proverb says "better wed over the mixen than over the moor").

[Insert Table 7 about here]

\section{Methods}

The aim of this section is to discuss the estimation strategy that we employed to study the relationship between top executives' turnover and bank performance, on the one hand, and banks' and managers' characteristics on the other. We will first address the issue of how to model this relationship within the context of a rather standard regression approach, and discuss the role played by unobservable bank and manager characteristics.

\subsection{The identification problem}

The idea behind our strategy is most simply understood by considering a standard regression model where $y_{i b t}$ is the outcome of interest for manager $i$ at bank $b$ at time $t$. For example, $y_{i b t}$ may be thought as our preferred measure of bank performance for bank $b$ at time $t$ when manager $i$ is appointed. Ideally, we would like to estimate the following equation:

$$
y_{i b t}=\alpha_{t}+\beta x_{i b t}+\eta_{i}+\zeta_{b}+\varepsilon_{i b t}
$$


where $x_{i b t}$ denotes a set of observable regressors which in general may vary across banks and managers as well as over time. In our application, these variables include bank size and characteristics of the manager such as age, education and connections. Note that in our definition connections are fixed over time because they are fully determined by the bank-/manager match. The variable $\alpha_{t}$ is simply a time effect, and can be modelled by year dummies or a flexible polynomial in time.

The remaining variables in the equation are unobservable error components. The term $\eta_{i}$ represents a fixed effect of the manager, that is, the set of characteristics which are relevant to $y_{i b t}$ but cannot be included amongst the regressors $x_{i b t}$ because they are not observable. The $\eta_{i}$ 's in equation (1) thus capture unobserved heterogeneity of managers in explaining the outcome $y_{i b t}$. Similarly, $\zeta_{b}$ represents a fixed effect of the bank. Note that neither of these components varies with time, the former being specific to the manager across appointments in different banks, and the latter being specific to the bank regardless of the manager appointed. Also note that different bank/manager matches are thus allowed to have heterogeneous effects on the outcome variable. Finally, the term $\varepsilon_{i b t}$ denotes a random error which we will assume throughout to be uncorrelated (across banks and managers, and over time) with the regressors $x_{i b t}$.

The identification of $\beta$, that is, of the marginal effect of $x_{i b t}$ on $y_{i b t}$, is of central interest in our analysis. However, estimates of this parameter obtained from the "feasible" regression of $y_{i b t}$ on $x_{i b t}$ may encounter an endogeneity problem. For example, if connections were perceived as a key component of human capital, more connected managers would be appointed in better organised banks, which would also be likely to have better performance on average. If this were the case, we would not be able to disentangle how much of the positive association between connections and performance depends solely on connections and how much of it is caused by confounding unobservable effects such as, for example, the bank's efficiency.

The specification in (1) explicitly allows for the presence of such confounding effects, in that it allows for omitted regressors which can be bank- or manager-specific but remain constant over time. Using micro data on banks and managers over time, one could estimate (1) by including dummies for managers and banks, and testing for the presence of confounding effects by considering their joint significance in the regression. Intuitively, for such a strategy to work one would need a sufficient degree of mobility of the same managers across banks over the time period considered. In the extreme case of no mobility of managers, we would not be able to disentangle the manager's fixed effect from the bank fixed effect. The setup discussed here closely resembles the 
identification problem dealt with by Abowd et al. (1999) in the case of matched employer/employee data (see also Kramarz and Thesmar 2006). ${ }^{7}$

\subsection{Modeling tenure at bank}

The discussion in the previous section helps clarify that unobserved heterogeneity plays a key role when modelling the duration of the manager's appointment. It is well known that duration analysis produces incorrect results if unobserved heterogeneity is ignored (see, for example, Lancaster 1990). To see this, let the hazard rate at time $\tau$ be defined as the probability of turnover during the $\tau$-th year at the bank conditional on the tenure attained until that year. On average, subjects with relatively high hazard rates for unobserved reasons leave the state of interest first, so that samples of survivors are selected. Differences between such samples at different times may then reflect behavioural differences as well as this selection effect.

In what follows we will model the survival probabilities of bank managers separately for the three positions considered and by bank type. Survival probabilities will be defined by following the bank/manager match over time from the first to the last year at the bank. We will present the results from a maximum likelihood estimation of mixed proportional hazards so as to take unobserved heterogeneity into account (see, for example, van den Berg 2001). We experimented with different assumptions about the distribution of the unobserved component, all of which led to qualitatively similar conclusions. For this reason, in what follows we will present the results from a complementary log-log model where the baseline hazard is modelled via a quadratic polynomial in (logged) time and the fixed effect term is normally distributed (see Jenkins 2005). ${ }^{8}$

We will present predicted survival probabilities for groups of observations defined by: (a) less and more connected managers, (b) Commercial and Saving Banks and Mutual, Cooperative and Rural Banks, and (c) "high"- and "low"-performing banks, these being banks performing in the top or the bottom $25 \%$ of the distribution of our preferred measure of performance respectively. ${ }^{9}$ Tests

\footnotetext{
7 It is worth noting that standard panel data modeling applied to model (1) does not help identify the causal effect of connections on the outcome $y_{i b t}$. In fact, standard fixed effect estimators of $\beta$ are obtained by regressing changes over time of the outcome variable (for example, changes in performance between two consecutive years when the manager $i$ is appointed at bank b) on changes over time of $x_{i b t}$. As pointed out earlier in this section, connections are fixed over time, given the bank/manager match. Hence identification of their effect on the outcome variable is precluded using this approach.

${ }^{8}$ It is worth noting that, as expected, unobserved heterogeneity comes significantly into play in modeling survival probabilities: all tests referring to the significance of this term rejected the null hypothesis of no effect at the conventional levels. Our approach to modeling the probability of turnover closely resembles that of Denis, Denis and Sarin (1997), who include tenure amongst the determinants of turnover and thus implicitly model the hazard rate. Similarly to their approach, our procedure estimates a discrete time hazard rate but explicitly models unobserved heterogeneity (see, for example, Jenkins 2005).

${ }^{9}$ In all the regressions considered, we allowed for nonlinearities in the effect of performance by adopting a specification in which performance affects survival probabilities through dummies referred to quartiles of the performance distribution.
} 
for the difference amongst survival probabilities for the above groups result in tests on suitably defined linear combinations of the coefficients of the variables entering the proportional hazards. ${ }^{10}$

We limited our analysis to complete or right-censored job durations by excluding from the analysis those matches for which we were unable to determine the starting date of the appointment. Alhough this is clearly a major source of selection in our working sample, we made this choice because accounting for left censoring would require assumptions on the starting time of the appointment at the bank which we found difficult to motivate in the context of this paper.

\subsection{Accounting for bank and manager unobserved heterogeneity}

As discussed above, estimation results from OLS may be severely biased because of unobservable characteristics that are omitted from the regression and are relevant to both performance and our measure of connection that follows from the bank/manager match. In addition to the duration analysis described in the previous section, we will therefore present regressions that exploit the panel dimension of our dataset in order to account for bank and manager unobserved heterogeneity. As pointed out earlier in this paper, however, we cannot make use of longitudinal information on bank/manager matches to estimate the effect of connections on performance, because our measure of connections is match-specific and does not vary over time. For this reason, standard within-group estimators would fail to identify the parameter of interest without additional assumptions.

To overcome this problem we exploited the additional source of variability consisting in the mobility of managers across banks over the period considered. We will thus focus on the subgroup of managers for whom there are multiple spells in the data in different banks: that is, the groups of managers to whom we referred as movers. Having repeated observations for the same managers in multiple banks, we will be able to control for manager's unobserved heterogeneity using standard panel data fixed effect estimation (see for example Abowd et al. 1999).

Since identification of the causal effects of connections relies upon the existence of movers, we characterized this group with respect to the variables in Table 1. We found that the key factors that characterize movers are bank type, position of the manager, and degree of connections. Perhaps as expected, we found that mobility is mainly concentrated in Commercial and Saving Banks, where on average around $20 \%$ of managers are appointed in more than one bank over the period considered (mobility being the highest for CEOs). Just over 3\% of managers in Mutual, Cooperative

\footnotetext{
${ }^{10}$ Throughout our analysis standard errors are robust to heteroskedasticity and take into account the fact that repeated measurements for bank/manager matches are available. Moreover, time effects are controlled for throughout our analysis by adding time dummies to all specifications considered. All the regressions considered allow for interactions of our measure of connections with performance, degree of local concentration of the bank, bank type and position of the manager either by running separate regressions for different groups of observations or including interaction terms amongst the explanatory variables.
} 
and Rural Banks actually move, and there are very few movers from one type of bank to the other, which indicates the existence of markets segmented by bank type. Moreover, on comparing the distribution of our measure of connections for movers in Table 8 against figures in Table 4, it appears that movers are on average less connected.

[Insert Table 8 about here]

\section{Results}

\section{$\underline{5.1 \text { Does performance matter for manager's survival? }}$}

In the set of figures that follows we will plot the profiles of predicted survival probabilities obtained as explained in Section 4.2 for "high" and "low" performing banks, separately for Commercial and Savings banks, and Mutual, Rural and Cooperative banks, by position of the manager at bank, and by the manager's degree of connection ("more" and "less" connected managers). The reason for the split by bank type is that Mutual, Rural and Cooperative banks are more local banks in the sense that they have smaller asset size, a higher concentration of operations (see Table 2), and a higher fraction of managers with distance equal to zero (see Table 4). Connections may therefore come into play for bank performance more for Mutual, Rural and Cooperative banks than for Commercial and Savings ones. We will classify banks depending on their accounting-based performance using both ROE and EBIDTA over Total Assets. The comparison of survival probabilities across groups will allow us to shed light on the ceteris paribus effects of connections and performance on the job tenure of managers at banks. The results for Presidents, CEOs, and General Managers are reported in Figures 1, 2, and 3, respectively. The right (left) hand side panel of each figure refers to predicted profiles for more (less) connected managers. P-values for the equality of curves within each panel are also presented.

One striking finding is that the survival probabilities of managers in low- and highperforming banks appear to be the same once connections are accounted for. This is confirmed by the fact that the difference between the two survival curves is not statistically significant. The only exception is that less connected General Managers in low-performing (by ROE) Commercial and Saving banks have a (marginally) statistically significant lower survival probability than their peers in high-performing banks (see the second panel of Figure 3a). We therefore find that performance per se does not greatly affect survival probability for all positions, for all banks, and for the two measures of performance considered once connections are accounted for. 


\subsection{Do connections affect manager's survival?}

In this section we directly assess how connections affect manager's survival. Intuitively, this amounts to testing whether the survival probabilities expressed by the dotted (continuous) lines in the left hand side panel of each graph differ on average from those given by the dotted (continuous) lines in the right hand side panel. To this end, we decided to run this test by looking at the coefficients of a suitably defined regression model. In the case of Presidents, our procedure consisted of the following steps. First, we pooled all the survival probabilities reported in Figures 1a and $1 \mathrm{~b}$, thus obtaining 8 point estimates (representing tenure at bank from the first to the eighth year) for 16 curves (for a total of 128 observations). We then specified the following regression equation:

$$
\log (S)=\beta_{0}+\beta_{1} T+\beta_{2} T^{2}+\beta_{3} C+\beta_{4} C \times T+\beta_{5} C \times T^{2}+u
$$

which models logged survival probabilities $\log (S)$ as a function of a quadratic polynomial in tenure $(T)$ and a dummy for the degree of connections $(C)$. Crucially, we allowed the curves to have different shapes for "more" and "less connected" managers ( $C=1$ and $C=0$, respectively) by letting the coefficients of the quadratic polynomial depend on the connections of managers. As additional regressors we considered group dummies defined for bank type and performance type, as well as the interaction between connection and performance type. We applied the same procedure to CEOs and General Managers, running separate regressions for the three positions considered.

The results of this test are presented in Table 9 and can be summarized as follows. ${ }^{11}$ First, more connected Presidents and General Managers have higher survival probabilities at a bank than their less connected peers. In particular, we found that the coefficients in (2) associated with connections are jointly significant at the conventional level, and that this translates into a positive effect of connections of around $25 \%$ and $20 \%$ on average over tenure for the two positions, respectively (see the first row of Table 9). The difference in survival probabilities between more and less connected CEOs is still positive (around 2.5\%) but not statistically different from zero. This result clearly reflects greater hazards (that is, a higher probability of losing the job conditional on tenure) for less connected Presidents and General Managers on average.

One additional dimension worth exploring is whether connections provide information on a manager's ability. If a well-connected manager is more likely to be personally known by the board of directors, then there should be less need to rely on external signals of his/her ability such as bank performance. For example, if there is informal evidence suggesting that the manager is of high ability, it may be easier to deduce that a poor bank performance is due to factors beyond the

\footnotetext{
${ }^{11}$ The full set of regression results is available from the authors upon request.
} 
manager's control and there is no reason to fire him/her. On this view, if connections capture only a "better-knowledge-of-the-manager effect", this should lead to large positive effects of connections on the hazard rate in the first years of work and to smaller effects as tenure increases. We should observe the same pattern if, over time, a less connected manager develops the same network of relationships and the same behaviour of a more connected manager: in this case, too, the impact of connections should weaken after the first years of work. To address this issue, for the three positions considered we tested whether the hazard rate remains constant with tenure or exhibits positive or negative duration dependence.

By using the definition of the hazard rate, $-\partial \log (S) / \partial T$, we decided to run this test by looking at the first derivative of the estimated polynomial in equation (2). ${ }^{12}$ Hazards rates increasing (decreasing) with tenure imply positive (negative) values of $-\partial^{2} \log (S) / \partial^{2} T$. If the hazard rates are not affected by tenure, the value of this second derivative must be zero. The results for the presence of duration dependence are presented in Table 9, which reports the values of the second derivative of $-\log (S)$ separately for "more connected" and "less connected" managers. According to the pvalues in the table, we cannot reject the hypothesis of constant hazards in all cases, thus ruling out any form of duration dependence. ${ }^{13}$

To summarize the results presented in this section, we can say that connections do not affect the shape of the hazard function, although they shift upwards the level resulting in higher risks for less connected managers. The gap caused by connections does not diminish with tenure; or put differently, tenure does not provide the manager with the advantages in terms of higher survival probability provided by local connections. Higher hazard functions are reflected in lower survival probabilities at bank, and we estimate that being more connected increases survival by around $20 \%$ and 25\% for General Managers and Presidents, respectively.

[Insert Table 9 about here]

\section{$\underline{5.3 \text { Do connections affect bank performance? }}$}

Local connections can have either a negative or a positive effect on bank performance. A negative interpretation views connections as collusion devices: everything else equal, the manager holds the position because s/he is local, regardless of his/her skills; and connections tend to protect

\footnotetext{
12 The same problem could have been addressed by considering the hazard functions underlying the survival probabilities in Figures 1, 2 and 3. However, since the conclusions presented in what follows are qualitatively identical to those resulting from the estimation of hazard functions discussed in Section 4.2, we decided to decide to rely on equation (2) as it provides a more synthetic way of presenting the results.

${ }^{13}$ We experimented with different specifications of equation (2), and in particular we allowed for differential effects of connections on survival probabilities across bank types. We found that the absence of any form of duration dependence holds true for either category of banks in our sample.
} 
the manager after poor bank performance. A more benign interpretation is that, since banking maintains a local dimension, connections are part of the manager's human capital. Being local would entail a better knowledge of the local economy and connections would allow more effective lobbying activity.

To investigate if and how employing local managers affects bank performance we adopted the following strategy. First, to have a proxy of the ease of collusion in each bank we considered two measures of the degree of localness of top management: the percentage of top managerial positions for which the value of the variable 'distance' is zero (i.e. the percentage of local managers), and the average value of the variable 'distance' for the positions considered at the bank. The idea is that the more local the top management, the easier it is to collude in maintaining and sharing rents.

We then regressed bank performance at each point in time on the average value of the above variables in the previous three years, in order to capture some dynamics in the composition of the top management, and all other available bank characteristics. Also, we added interactions of our indicators of localness of management with the degree of geographic concentration of the bank's operation to study whether the effects of connections vary with the localness of the bank. ${ }^{14}$ The regressions thus consider only one observation per bank at each point in time and allow for unobserved bank heterogeneity through fixed effects estimation.

[Insert table 10 about here]

The results for the key variables considered, which proved robust to alternative specifications of the regression equation, are reported in columns (1) and (2) of Table 10 using ROE and EBITDA over Total Assets, respectively. Table 10 reports the key estimation findings discussed here and in the next section. Connections, as measured by the average value of the variable 'distance' for the top management in the past three years, appear to have a marginally significant effect only on the latter indicator of performance (see the p-values at the end of the Table). In particular, according to the results in column (2), the returns to having top managements with marginally higher values of the variable 'distance' increase with the bank's degree of concentration (the interaction term being positive), thus implying that having more connected managers is comparatively less advantageous for banks with more geographically concentrated operations. Point estimates using the results in column (1), though not statistically significant, suggest the same conclusion. Similarly, using the coefficients reported in the table one can show that the returns to having top managements with a higher proportion of connected managers are

\footnotetext{
${ }^{14}$ Since Commercial and Savings banks have far less geographical concentrated operations than do Mutual, Rural and Cooperative banks (see Table 2) classifying banks by the variable concentration guarantees continuity with the stratification of banks adopted in Section 5.1.
} 
negative, though not statistically different from zero, for banks for which the value of the concentration index is above $80 \%$.

\section{[Insert table 11 about here]}

As the above results do not take characteristics of the top management into account, as a sensitivity check we complement this part of the analysis by directly modelling the heterogeneity of top managers. In this regard, we report two additional sets of results. First, in columns (1) and (3) of Table 11 we present regression results of bank performance (for ROE and EBITDA over Total Assets, respectively) on a flexible specification in bank and manager characteristics, dummies for the position of the manager at the bank, a second order polynomial in the value of the variable 'distance', and a dummy for distance equal to zero. As before, we interacted all variables referring to connections with the concentration index and we explicitly allowed for unobserved bank heterogeneity by including dummy variables for banks in the regression. Differently from what we did in Table 10, we now use multiple observations per bank at each point in time referring to all managers appointed and take characteristics of the managers into account. Looking at point estimates shows that the relationship between performance and the variable 'distance' is non-linear, depicting basically flat profiles of ROE with respect to distance - column (1) - and profiles of EBITDA over Total Assets which are increasing with distance - column (3). The results in either column, however, confirm that our measure of connections does not play a statistically significant role in causing better performance. In particular, the returns to having distance equal to zero are not statistically different from zero for either measure of bank performance (see the p-values at the bottom of the two columns).

Second, to show the role played by managers' unobserved heterogeneity (such as geographic preferences), in columns (2) and (4) of Table 11 we report an attempt jointly to model bank and manager unobserved heterogeneity (again for ROE and EBITDA over Total Assets, respectively). As explained in Section 4.3, to disentangle the effect of connections and retrieve their causal effect on performance we took a quite novel approach and used only observations for movers, that is, managers appointed in more than one bank over the time period covered by our analysis (the same approach has been used by Kramarz and Thesmar 2006). We maintained the same specification of the regression equations estimated in columns (1) and (3) of Table 11, and we added in as additional regressors dummy variables for movers. Bearing in mind the above caveats concerning the much smaller sample size, only EBITDA over Total Assets appears to depend upon values of the variable 'distance' - see column (4). On drawing the profiles implied by point estimates one would in fact conclude that higher values of performance correspond to less connected managers, uniformly 
across values of the concentration index of the bank. However, the returns to having distance equal to zero are again not statistically different from zero.

Overall, according to the results presented in this section there is no evidence of positive returns to having well-connected top managers in the bank. If anything, the results for banks with a high degree of geographic concentration, where connections are most likely to play an important role, suggest that the returns to connections may be negative. These conclusions appear to be robust to the presence of unobserved bank and manager characteristics. The above findings are instead consistent with the hypothesis that connections are collusion devices - a hypothesis that we subject to further testing in the next subsection.

\section{$\underline{5.4 \text { Do connections affect bank's survival? }}$}

A well-known drawback to accounting-based measures of performance is that they can be manipulated by the managers, and for Mutual, Rural and Cooperative banks they may also reflect their mutual nature. The ability to manipulate performance measures is, for example, a possible explanation suggested by Barro and Barro (1990) for why CEO turnover in U.S. commercial banks is not related to accounting measures, whilst it is negatively related to market measures like stock performance. Thus the regression results presented in Tables 10 and 11 may be affected by the scant information content of the performance indicators. This problem could have been overcome if harder-to-manipulate measures of performance, like stock returns, were available. Unfortunately, this is not the case, since, as mentioned, only a small fraction of Italian banks are listed.

However, the large number of mergers and acquisitions that took place among Italian banks in the sample period may provide some, albeit indirect, information about bank performance. Although almost all the mergers and acquisitions were "friendly", and some of them were merely rescue operations orchestrated by the Bank of Italy, the loss of control and of bank independence, and, in some cases the bank's disappearance itself, may be indicators of a negative performance. When a bank is merged into another, the top managerial positions considered disappear, with the likely loss of whatever power and rents they may have generated for their holders. Hence, whilst protracted losses may be masked by opaque accounting, poor performance eventually threatens the bank's very survival. Using the probability of bank survival as a measure of bank performance we follow other studies (e.g. Prowse 1995, Crespì et al. 2004) documenting a positive relationship between the probability of a bank's survival and its performance. For example Crespì et al. (2004) find that for Spanish Saving banks the only significant relationship between performance and governance intervention seems to be in the case of mergers. 
We then complemented the results in the previous section by exploring the possibility that connections may negatively affect the survival of banks. ${ }^{15}$ Columns (3) and (4) of Table 10 present results from a conditional logit regression of the variable "bank not existing at time $t$ " on the same set of regressors considered in columns (1) and (2), controlling for the mean value over the last three years of the dummies for quartiles of performance (using ROE and EBITDA over Total Assets). The results point to a negative effect of the top management's degree of localness on bank survival. The percentage of managers with distance equal to zero and its interaction with the index of geographical concentration of the bank are jointly significant for either measure of bank performance. Point estimates imply that banks for which the value of the index is above $30 \%$ present negative returns to higher proportions of local managers on the survival probability. Since this effect increases with the bank's degree of geographical concentration, the result is consistent with the hypothesis that connections are particularly strong collusion devices for locally concentrated banks.

To sum up, we find no evidence in favour of the hypothesis that the information content of managerial connections gives a positive contribution to bank performance. Our evidence instead suggests that connections are devices used to maintain and share managerial rents, and are thus detrimental to bank performance. This is not directly visible when the more opaque accountingbased measures of performance are used, but it is captured by a more crude measure of performance like the probability of the bank's survival. Consistently with the hypothesis that connections are collusion devices, we find that connections are only to the benefit of the top managers themselves, whose survival probability (for Presidents and General Managers) significantly increases with connections. In light of these findings, also the result that performance does not greatly affect bankers' turnover once connections are accounted for is consistent with the hypothesis that connections do not add value for the bank but instead shield managers from turnover after poor performance.

\section{Conclusions}

We have studied bank performance and manager's local connections as determinants of managerial turnover in Italian banks for two reasons. First, banking is an information-sensitive industry where connections are potentially important. Second, Italy is a particularly interesting case because recent regulatory changes have strengthened the importance of market forces, while preserving an environment where local connections still play an important role. Our research

\footnotetext{
${ }^{15}$ Note that in this case a survival analysis like the one presented in Section 5.1 would seriously suffer from left censoring, which affects over $90 \%$ of banks in our sample. For this reason, we decided not to model the hazard rates and instead used the regression approach described in what follows.
} 
complements the existing literature on banker's turnover by moving in a new direction where studies on social networks are integrated with the more traditional investigation of corporate governance in banking.

We have measured the degree of local connections of bankers by the distance between the province of the bank headquarters and the banker's province of birth. The top managers of Italian banks tend to be local in the sense that the distance is rather small, and in fact was zero for the large majority of observations in our sample. The degree of connection varies greatly for different types of manager, with Presidents being more local especially in Mutual, Rural and Cooperative banks. We find that connections generally increase the survival probabilities of Presidents and General Managers, and that the positive effect of performance on tenure (which has been widely documented by the executive turnover literature) disappears once connections are accounted for.

There is no evidence of positive returns to having well-connected top managers in the bank. If anything, the results for banks with a high degree of geographic concentration, where connections are most likely to play an important role, suggest that the returns may be negative. We instead find evidence that connections reduce the survival probability of banks, which is consistent with the hypothesis that connections are devices used to share and maintain local rents at the expenses of the bank's performance, broadly defined to include survival. 


\section{References}

Abowd, J., F. Kramarz, D. Margolis (1999), "High-Wage Workers and High-Wage Firms" Econometrica 67, 251-333.

Bandiera, O., I. Barankay, I. Rasul (2007) "Social Connections and Incentives in the Workplace: Evidence from Personnel Data" forthcoming in Econometrica.

Barro, J. and R. Barro (1990) "Pay, Performance, and Turnover of Bank CEOs" Journal of Labor Economics 8, 448-481.

Bhattacharya, S. and G. Chiesa (1995) "Proprietary Information, Financial Intermediation, and Research Incentives" Journal of Financial Intermediation 4, 328-357.

Brunello, G., C. Graziano and B. M. Parigi (2003) "CEO Turnover in insider-dominated boards: The Italian case" Journal of Banking and Finance, 27, 1027-1051.

Carling, K. and S. Lundberg (2005) "Bank Lending, Geographical Distance, and Credit risk: An Empirical Assessment of the Curch Tower Principle" Journal of Economic and Business 1, 39-59.

Casolaro, L. and P.E. Mistrulli (2007) "Distance, Organizational Structure and Loan Interest Rates" Bank of Italy, mimeo.

Cingano, F. and A. Rosolia (2007) "People I Know: Workplace Networks and Job Search Outcomes" Temi di Discussione N. 600, Economic Research Department, Bank of Italy.

Crespì, R., M. Garcia-Cestona and V. Salas (2004) "Governance mechanisms in Spanish banks. Does ownership matter?” Journal of Banking and Finance, 28, 2311-2330.

Degryse, H. and S. Ongena, (2005) "Distance, Lending Relationship, and Competition" Journal of Finance 1, 231-66.

Denis, D., D. Denis and A. Sarin (1997) "Ownership structure and Top Executive Turnover" Journal of Financial Economic, 10, 72-80.

Faccio, M. (2006) “Politically Connected Firms” American Economic Review, 96, 369-386.

Focarelli, D., F. Panetta, C. Salleo (2002) "Why do Banks Merge?" Journal of Money Credit and Banking 34, 1047-1066.

Frazzini, A., C. Malloy and L. Cohen (2008) “Sell side school ties” NBER working paper 13973.

Goyal, S. (2007) "Connections: An Introduction to the Economics of Networks" Princeton University Press, Princeton NJ.

Guiso, L., P. Sapienza and L. Zingales (2005) "The Role of Social Capital in Financial Development" American Economic Review 94, 3, 526-56.

Guiso, L., P. Sapienza and L. Zingales (2006) “The cost of banking regulation” NBER working paper 12501. 
Houston, J. and C. James (1995) "CEO Compensation and Bank risk: is compensation in Banking structured to promote risk taking?" Journal of Monetary Economics, 36, 405-431.

Kramarz, F. and D. Thesmar (2006) "Social Networks in Board Room” CEPR WP 5496.

Ioannides Y. and D. Loury (2004) "Job Information Networks, Neighborhood Effects and Inequality" Journal of Economic Literature 42, 1056-1093.

Jenkins, S. P. (2005) "Survival Analysis" Unpublished manuscript, Institute for Social and Economic Research, University of Essex, Colchester, UK. Downloadable from:

http://www.iser.essex.ac.uk/teaching/degree/stephenj/ec968/pdfs/ec968lnotesv6.pdf.

Lancaster, T. (1990) “The Econometric Analysis of Transition Data”. Cambridge: Cambridge University Press.

Malloy, C. (2005) “The Geography of Equity Analysis” Journal of Finance, 60, 2, 719-755.

Morck, R., A. Shleifer and R. W. Vishny (1989), "Alternative Mechanisms for Corporate Control" American Economic Review, 79, 4, 842-852.

Nguyen-Dang B. (2006) "Does the Rolodex Matter? Corporate Elite's Small World and the Effectiveness of Board of Directors" SSRN: http://ssrn.com/abstract=864184

Panetta, F. (a cura di) (2004) Il sistema bancario negli anni novanta. Gli effetti di una trasformazione, Il Mulino, Bologna.

Petersen, M. and R. Rajan (1994) "The Benefits of Lending Relationships: Evidence from Small Business Data" Journal of Finance 49, 3-37.

Petersen, M. and R. Rajan (2002) "Does Distance Still Matter? The Information Revolution in Small Business Lending" Journal of Finance, 57, 2533-2570.

Prowse, S. (1995) “ Alternative methods of corporate control of Commercial banks" Federal Reserve Bank of Dallas Economic Review, Third Quarter, 24-36.

Sapienza, P. (2004) "The effects of Government Ownership on Bank Lending," Journal of Financial Economics, 72, 357-384.

Stein, J.C. (2002) "Information production and capital allocation: Decentralized Versus Hierarchical Firms" Journal of Finance 57, 1891-1921.

Subrahmanyam, A. (2008) "Social Networks and Corporate Governance," European Financial Management, 14, 633-662.

van den Berg, G.J. (2001), "Duration models: Specification, identification, and multiple durations", in J.J. Heckman and E. Leamer, editors, Handbook of Econometrics, Volume V, North Holland, Amsterdam. 


\begin{tabular}{|c|c|c|}
\hline \multicolumn{3}{|c|}{ Table 1: List of Variables } \\
\hline \multicolumn{3}{|c|}{ Manager characteristics } \\
\hline Variable name & Description & Source \\
\hline Age & Age of the manager & Telemaco \\
\hline Education & High School Graduate, College Graduate & ABI Yearbook \\
\hline Position at bank & President, CEO, General Manager & ABI Yearbook \\
\hline Place of Birth & Province of birth & Telemaco \\
\hline Foreign born & Dummy for born abroad & Telemaco \\
\hline Distance & Degree of connection & $\begin{array}{l}\text { http://www.stata.com/u } \\
\text { sers/brising }\end{array}$ \\
\hline Honorary title & Dummy for honorary title & ABI Yearbook \\
\hline \multicolumn{3}{|c|}{ Bank characteristics } \\
\hline Variable name & Description & Source \\
\hline Total Assets & Asset values at current prices & Bilbank \\
\hline City bank & $\begin{array}{l}\text { Dummy for banks headquartered in a provincial } \\
\text { capital }\end{array}$ & ISTAT \\
\hline Bank type & Dummy for Commercial and Savings banks & Bilbank \\
\hline Head & Dummy for banks head of a bank holding company & Bilbank \\
\hline Independent bank & $\begin{array}{l}\text { Dummy for banks not part of any bank holding } \\
\text { company }\end{array}$ & Bilbank \\
\hline Listed & Dummy for listed banks & Bilbank \\
\hline Headquarter area & Dummies for Northern, Central and Southern Italy & Bilbank \\
\hline Concentration & $\begin{array}{l}\text { Fraction of branches in the province of the bank's } \\
\text { headquarters }\end{array}$ & Bank of Italy \\
\hline EBITDA & $\begin{array}{l}\text { Earnings before interests, taxes, depreciation, and } \\
\text { amortization }\end{array}$ & Bilbank \\
\hline $\begin{array}{l}\text { Non-performing } \\
\text { loans }\end{array}$ & Non performing loans/Total loans & Bilbank \\
\hline ROE & Return on Equity & Bilbank \\
\hline
\end{tabular}




\begin{tabular}{|c|c|c|}
\hline $\begin{array}{l}\text { Commercial, and saving banks } \\
\text { (number of observations 3532) }\end{array}$ & Mean & Standard deviation \\
\hline \multicolumn{3}{|l|}{ Fraction of banks which are: } \\
\hline City bank & 0.72 & 0.45 \\
\hline Independent & 0.40 & 0.49 \\
\hline Listed & 0.20 & 0.40 \\
\hline Head of bank holding company & 0.25 & 0.44 \\
\hline Located in Central Italy & 0.20 & 0.40 \\
\hline Located in Southern Italy & 0.23 & 0.42 \\
\hline Assets (in log) & 2.72 & 0.13 \\
\hline $\mathrm{ROE}$ & 0.006 & 0.669 \\
\hline EBITDA/Total Assets & 0.016 & 0.013 \\
\hline Concentration & 0.66 & 0.29 \\
\hline $\begin{array}{l}\text { Mutual, cooperative, and rural banks } \\
\text { (number of observations 4839) }\end{array}$ & Mean & Standard deviation \\
\hline \multicolumn{3}{|l|}{ Fraction of banks which are: } \\
\hline City bank & 0.08 & 0.27 \\
\hline Independent & 0.95 & 0.21 \\
\hline Listed & 0.02 & 0.17 \\
\hline Head of bank holding company & 0.03 & 0.16 \\
\hline Located in Central Italy & 0.15 & 0.36 \\
\hline Located in Southern Italy & 0.27 & 0.44 \\
\hline Assets (in log) & 2.52 & 0.12 \\
\hline ROE & 0.082 & 0.076 \\
\hline EBITDA/Total Asset & 0.015 & 0.008 \\
\hline Concentration & 0.92 & 0.17 \\
\hline
\end{tabular}




\begin{tabular}{|c|c|c|}
\hline & $\begin{array}{c}\text { Commercial and Savings } \\
\text { banks }\end{array}$ & $\begin{array}{c}\text { Mutual, Cooperative and } \\
\text { Rural banks } \\
\end{array}$ \\
\hline \multicolumn{3}{|l|}{ President } \\
\hline Age in years & 64.12 & 57.28 \\
\hline$\%$ with college degree & 85.1 & 61.7 \\
\hline$\%$ with honorary title & 12.1 & 11.3 \\
\hline \multicolumn{3}{|l|}{ CEO } \\
\hline Age in years & 57.62 & na \\
\hline$\%$ with college degree & 71.3 & na \\
\hline$\%$ with honorary title & 6.5 & na \\
\hline \multicolumn{3}{|l|}{ General Manager } \\
\hline Age in years & 55.36 & 51.94 \\
\hline$\%$ with college degree & 65.2 & 32.6 \\
\hline$\%$ with honorary title & 4.2 & 1.0 \\
\hline
\end{tabular}

Table 4: Distribution of the distance between the province of the bank's headquarters and the manager's province of birth, for Mutual, Cooperatives, and Rural Banks, and for Commercial and Saving Banks by position held by the manager. Distance is defined as the distance between the geographical coordinates of two provinces corrected for the earth surface curvature, in kilometres. For example, the entry 90.59 below indicates that $75 \%$ of the General Managers of Mutual, Cooperatives, and Rural Banks were born in provinces at a distance $\leq 90.59 \mathrm{~km}$ from the province of the bank's headquarters. An entry 0.00 in column $50 \%$ indicates that the median manager in that category was born in the same province as the bank's headquarters; 1993-2001. For a description of the other variables and their sources see Table 1.

\begin{tabular}{|l|c|c|c|c|c|}
\hline \multicolumn{7}{|c|}{ Mutual, Cooperatives, and Rural Banks } \\
\hline & $5 \%$ & $25 \%$ & $50 \%$ & $75 \%$ & $95 \%$ \\
\hline President & 0.00 & 0.00 & 0.00 & 0.00 & 112.45 \\
\hline General Manager & 0.00 & 0.00 & 0.00 & 90.59 & 625.23 \\
\hline \multicolumn{7}{|c|}{ Commercial and Saving Banks } \\
\hline President & 0.00 & 0.00 & 0.00 & 83.47 & 500.83 \\
\hline CEO & 0.00 & 0.00 & 96.32 & 365.40 & 787.69 \\
\hline General Manager & 0.00 & 0.00 & 75.70 & 249.77 & 709.60 \\
\hline
\end{tabular}




\begin{tabular}{|l|c|c|}
\hline $\begin{array}{l}\text { Table 5: Distance by education level and honorary title. Average distance between the province of the } \\
\text { bank's headquarters and the manager's province of birth for President, CEO, and General Manager, by } \\
\text { education level, and honorary title; 1993-2001. Distance is defined by the distance between the } \\
\text { geographical coordinates of two provinces corrected for the earth surface curvature. For a description of } \\
\text { the other variables and their sources see Table 1. }\end{array}$ Wistance in Km \\
\hline & With College degree & W/out College degree \\
\hline & 65.04 & 20.55 \\
\hline President & 161.97 & 134.06 \\
CEO & 204.44 & 122.08 \\
General Manager & \multicolumn{2}{|c|}{ P-value for no association: 0.000} \\
\hline & \multicolumn{2}{|c|}{ Distance in Km } \\
\hline & With Honorary title & W/out Honorary title \\
\hline President & 35.34 & 54.07 \\
CEO & 172.73 & 236.90 \\
General Manager & 186.17 & 167.62 \\
\hline \multicolumn{2}{|c|}{ P-value for no association: 0.000} \\
\hline
\end{tabular}

Table 6: Average tenure (in years) of Presidents, CEOs and General Managers by bank category. Results were obtained by fitting a lognormal parametric model to take right censoring into account. Separate models were estimated for the three positions considered.

\begin{tabular}{|l|c|c|c|c|}
\hline \multicolumn{1}{|c|}{ Category of banks } & President & CEO & General Manager & Total \\
\hline Commercial and Savings banks & 7.09 & 4.31 & 3.73 & 5.37 \\
\hline Mutual, Cooperatives, and Rural banks & 9.99 & na & 3.86 & 9.10 \\
\hline
\end{tabular}




\begin{tabular}{|c|c|c|c|c|c|c|}
\hline \multirow{2}{*}{$\begin{array}{l}\text { Years in the } \\
\text { position }\end{array}$} & \multicolumn{2}{|c|}{ Presidents } & \multicolumn{2}{|c|}{ CEOs } & \multicolumn{2}{|c|}{ General Managers } \\
\hline & $\begin{array}{c}\text { Less } \\
\text { connected }\end{array}$ & $\begin{array}{c}\text { More } \\
\text { connected }\end{array}$ & $\begin{array}{c}\text { Less } \\
\text { connected }\end{array}$ & $\begin{array}{c}\text { More } \\
\text { connected }\end{array}$ & $\begin{array}{c}\text { Less } \\
\text { connected }\end{array}$ & $\begin{array}{c}\text { More } \\
\text { connected }\end{array}$ \\
\hline 1 & 0.86 & 0.94 & 0.93 & 1.00 & 0.84 & 0.86 \\
\hline 2 & 0.76 & 0.85 & 0.78 & 0.87 & 0.64 & 0.77 \\
\hline 3 & 0.66 & 0.74 & 0.61 & 0.67 & 0.52 & 0.69 \\
\hline 4 & 0.48 & 0.68 & 0.43 & 0.50 & 0.37 & 0.60 \\
\hline 5 & 0.38 & 0.62 & 0.37 & 0.50 & 0.28 & 0.53 \\
\hline 6 & 0.32 & 0.57 & 0.29 & 0.50 & 0.26 & 0.53 \\
\hline 7 & 0.27 & 0.48 & 0.29 & 0.50 & 0.23 & 0.48 \\
\hline $\begin{array}{l}\text { Log-Rank test } \\
\text { for equality of } \\
\text { survival } \\
\text { functions }\end{array}$ & \multicolumn{2}{|c|}{ P-value: 0.000} & \multicolumn{2}{|c|}{ P-value $=0.2727$} & \multicolumn{2}{|c|}{$\mathrm{P}$-value $=0.005$} \\
\hline
\end{tabular}

Table 8: Distance for movers. Distribution of the distance between the province of the bank's headquarters province and the manager's province of birth (only movers). For a description of the variable 'distance' see Table 5.

\begin{tabular}{|c|c|c|c|c|c|}
\hline \multicolumn{6}{|c|}{ Commercial and Savings banks (number of observations: 681) } \\
\hline & $5 \%$ & $25 \%$ & $50 \%$ & $75 \%$ & $95 \%$ \\
\hline $\begin{array}{l}\text { President } \\
\text { (number of obs.: 197) }\end{array}$ & 0.00 & 0.00 & 68.04 & 201.31 & 483.45 \\
\hline $\begin{array}{l}\text { CEO } \\
\text { (number of obs.: 167) }\end{array}$ & 0.00 & 30.85 & 79.52 & 246.85 & 826.66 \\
\hline $\begin{array}{l}\text { General Manager } \\
\text { (number of obs.: } 317 \text { ) }\end{array}$ & 0.00 & 36.58 & 135.17 & 300.21 & 738.65 \\
\hline \multicolumn{6}{|c|}{ Mutual, Cooperatives and Rural banks (number of observations: 163) } \\
\hline & $5 \%$ & $25 \%$ & $50 \%$ & $75 \%$ & $95 \%$ \\
\hline $\begin{array}{l}\text { President } \\
\text { (number of obs.: 95) }\end{array}$ & 0.00 & 0.00 & 0.00 & 0.00 & 79.82 \\
\hline $\begin{array}{l}\text { General Manager } \\
\text { (number of obs.: } 68 \text { ) }\end{array}$ & 0.00 & 0.00 & 48.23 & 141.59 & 588.17 \\
\hline
\end{tabular}


Figure 1a. Percentage of surviving Presidents. Survival probabilities of more connected (distance $=0$ ) and less connected (distance >0) managers for low performing banks (bottom 25\% of the distribution of ROE and high performing banks (top $25 \%$ of the distribution of ROE.

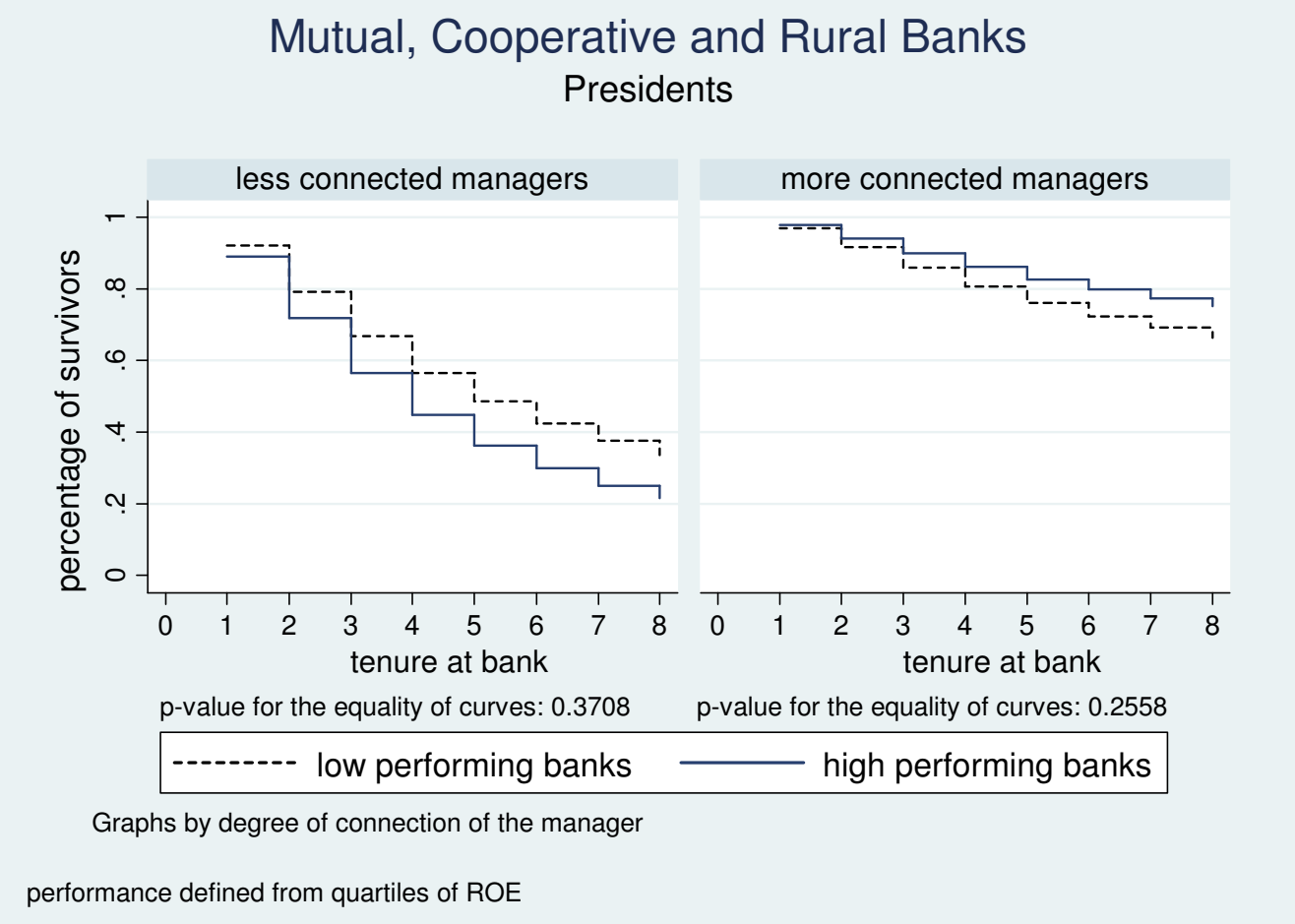

\section{Commercial and Saving Banks \\ Presidents}

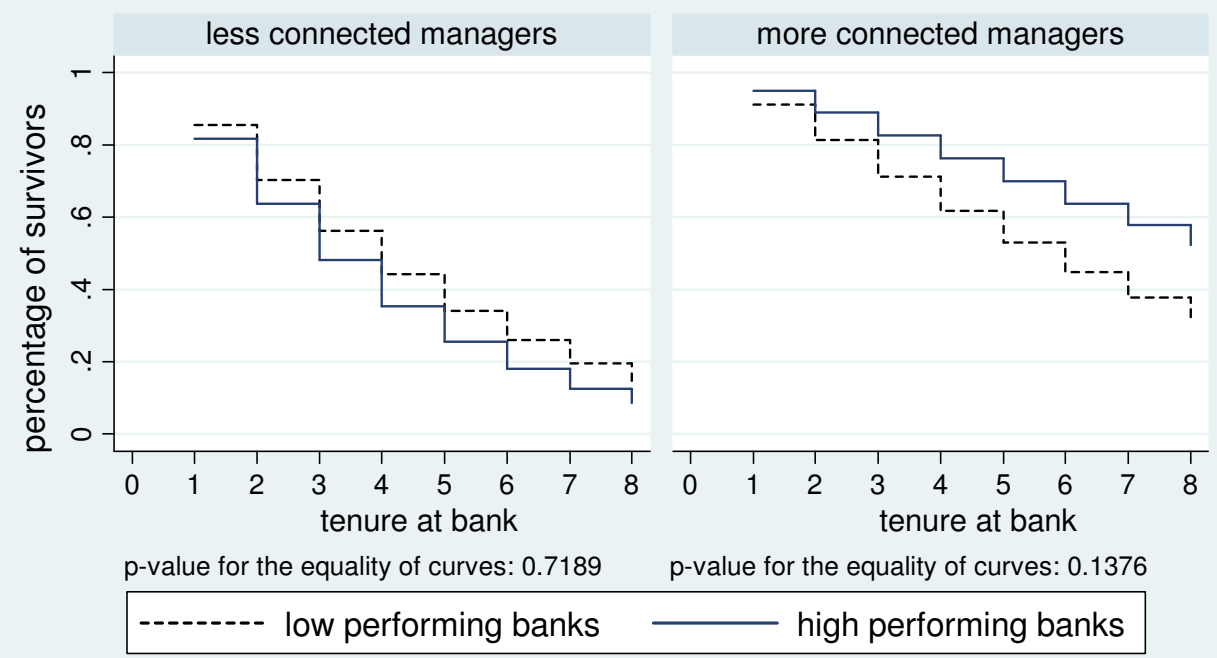

Graphs by degree of connection of the manager

performance defined from quartiles of ROE 
Figure 1b. Percentage of surviving Presidents. Survival probabilities of more connected (distance $=0$ ) and less connected (distance $>0$ ) managers for low performing banks (bottom 25\% of the distribution of EBITDA/Total Assets) and high performing banks (top $25 \%$ of the distribution of EBITDA/Total Assets).

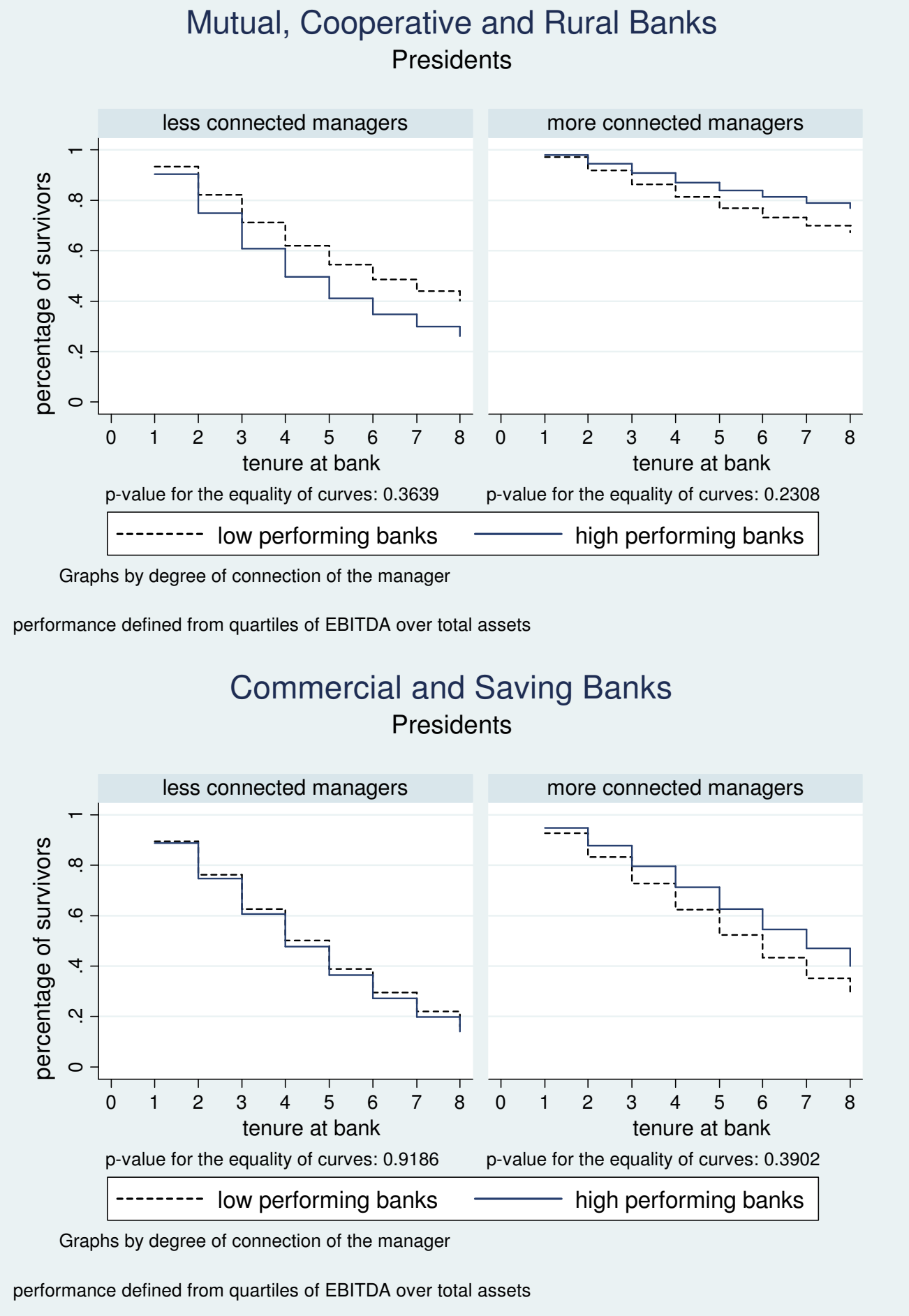


Figure 2. Percentage of surviving CEOs Survival probabilities of more connected (distance $=0$ ) and less connected (distance > 0) managers for low performing banks (bottom 25\% of the distribution of ROE or EBITDA/Total Assets) and high performing banks (top 25\% of the distribution of ROE or EBITDA/Total Assets).
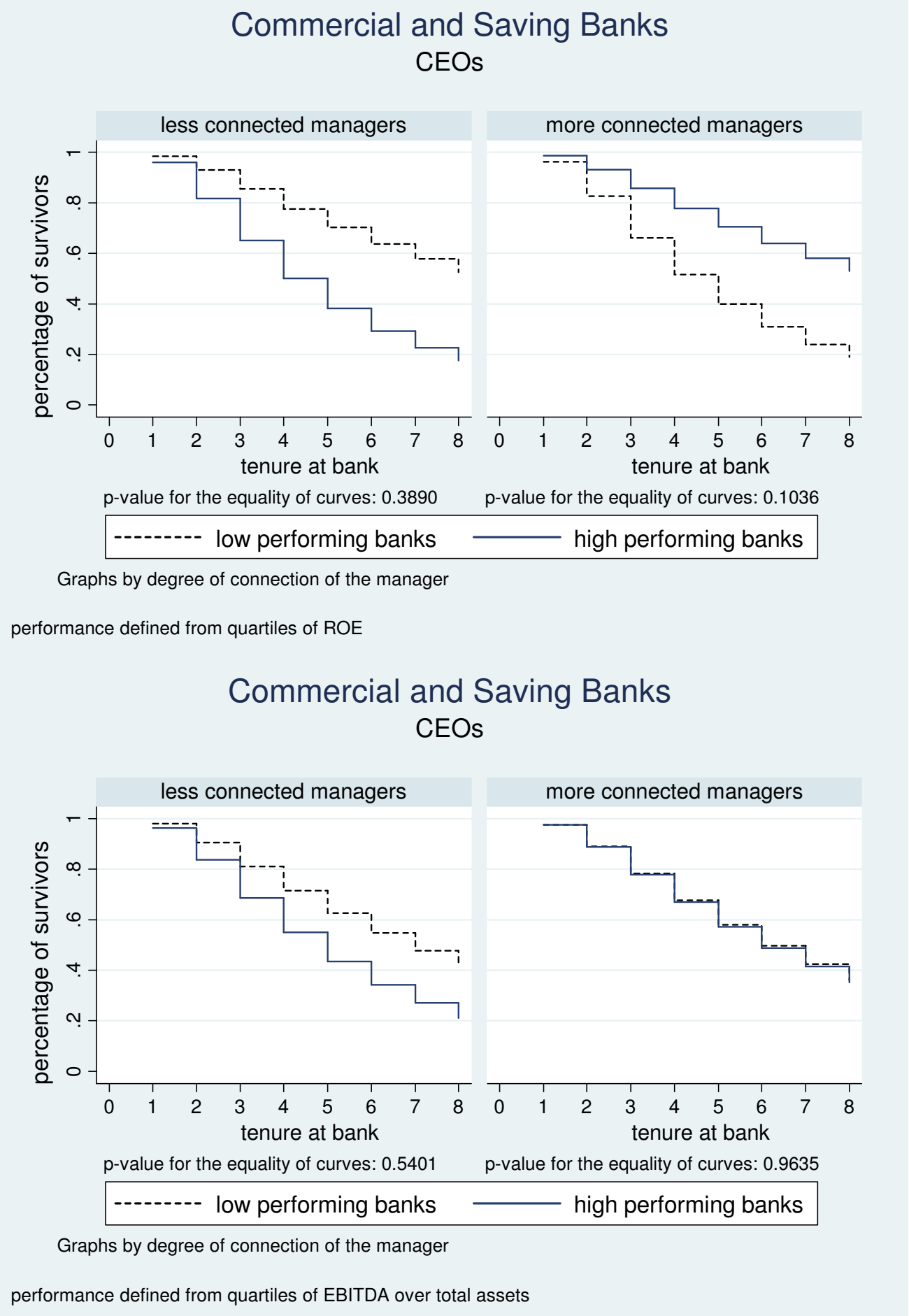
Figure 3a. Percentage of surviving General Managers. Survival probabilities of more connected (distance $=0)$ and less connected (distance > 0) managers for low performing banks (bottom 25\% of the distribution of ROE and high performing banks (top $25 \%$ of the distribution of ROE.

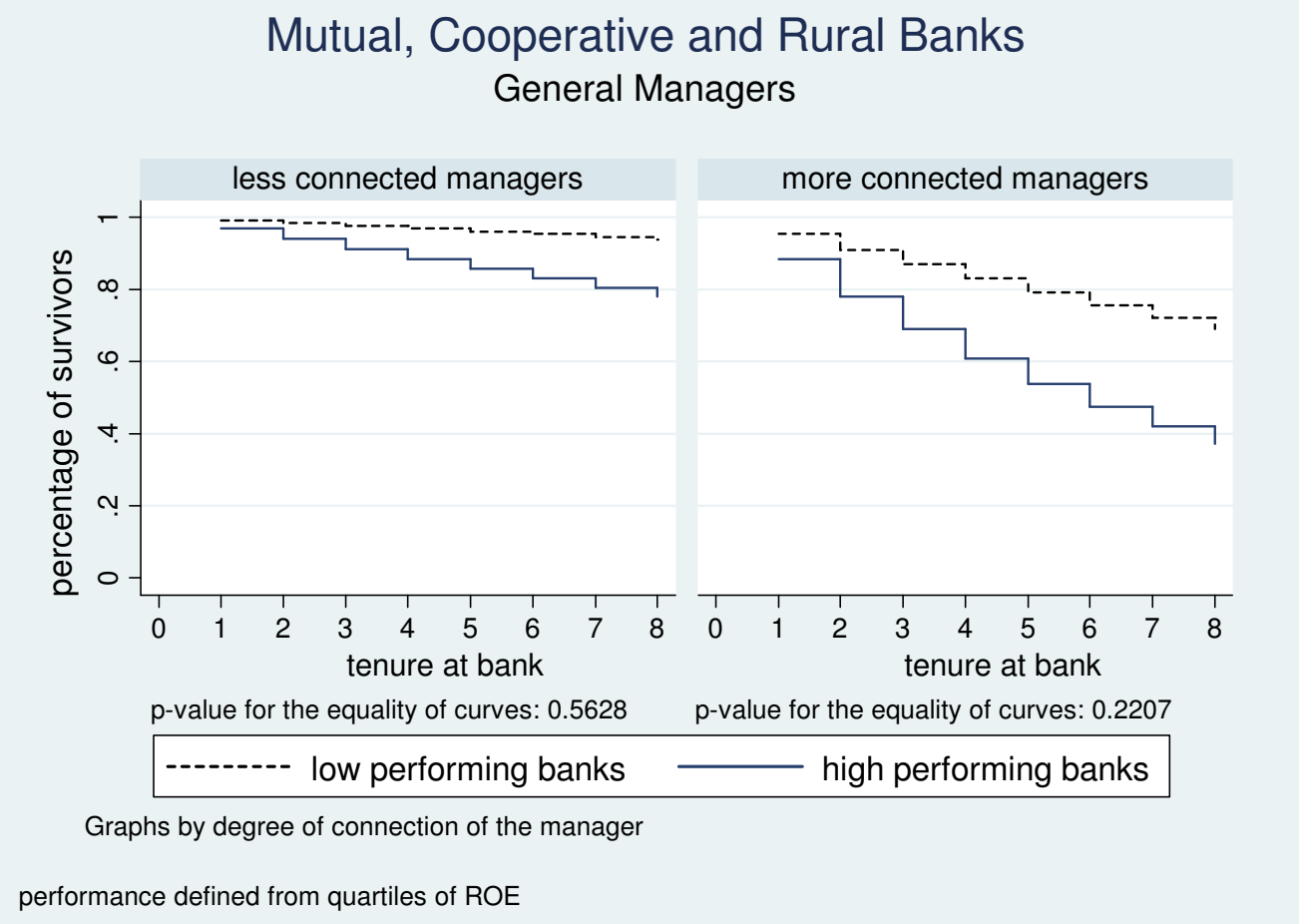

\section{Commercial and Saving Banks \\ General Managers}

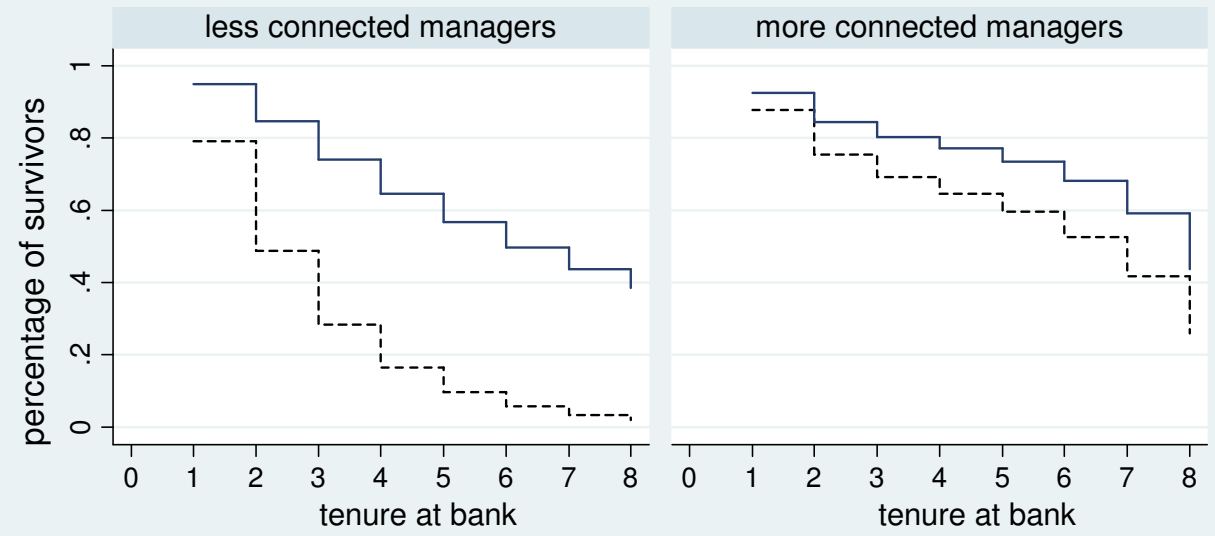

p-value for the equality of curves: 0.0680

$p$-value for the equality of curves: 0.2540

-.--- low performing banks high performing banks

Graphs by degree of connection of the manager

performance defined from quartiles of ROE 
Figure 3b. Percentage of surviving General Managers. Survival probabilities of more connected (distance $=0)$ and less connected (distance > 0) managers for low performing banks (bottom 25\% of the distribution of EBITDA/Total Assets) and high performing banks (top 25\% of the distribution of EBITDA/Total Assets).

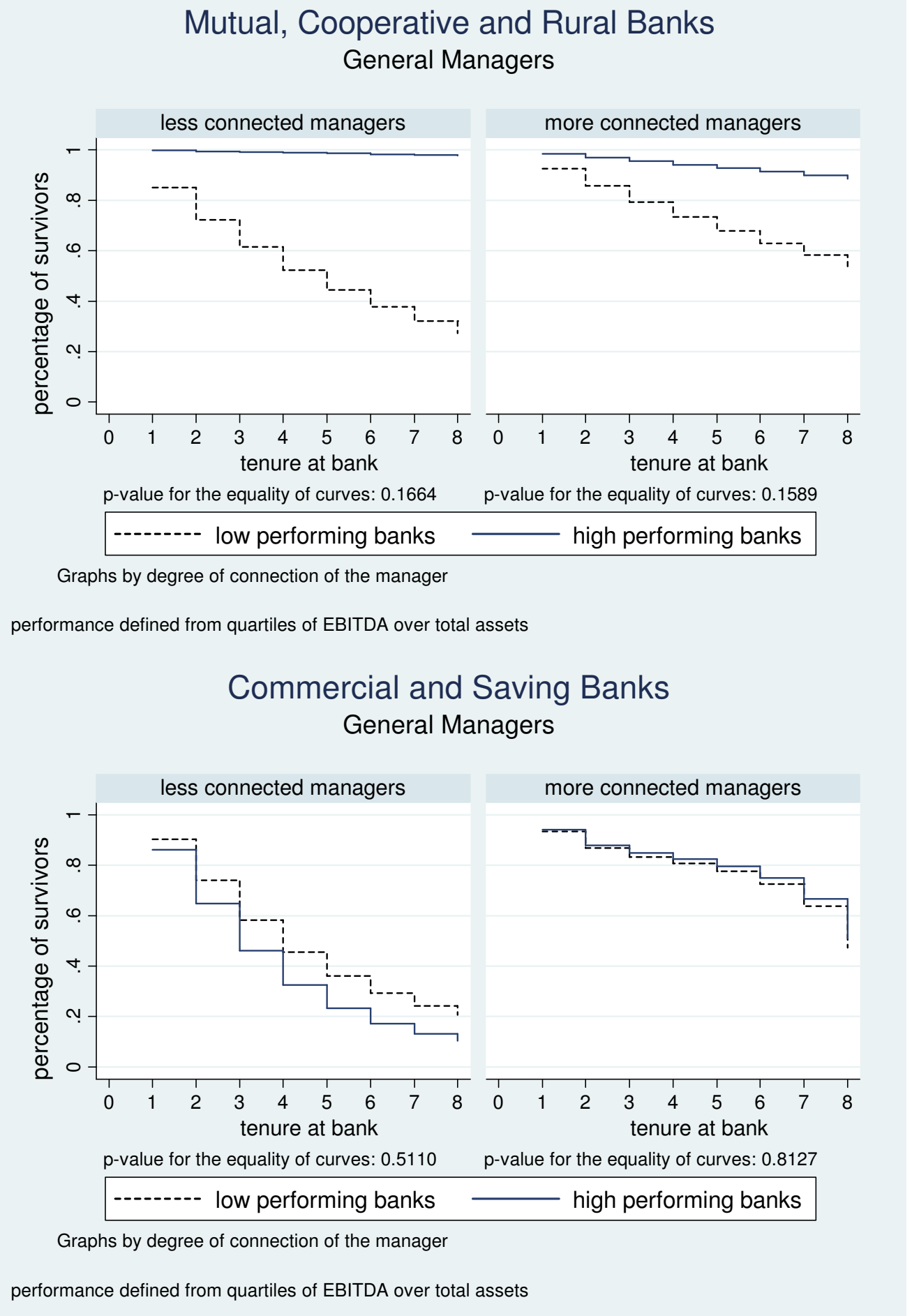




\begin{tabular}{|c|c|c|c|c|}
\hline & & Presidents & CEOs & $\begin{array}{c}\text { General } \\
\text { Managers }\end{array}$ \\
\hline $\begin{array}{l}\text { Average difference in sur } \\
\text { and "less-connected" manc }\end{array}$ & $\begin{array}{l}\text { ival probabilities between "more" } \\
\text { gers. }\end{array}$ & $\begin{array}{l}24.76 \% \\
(0.0000)\end{array}$ & $\begin{array}{l}2.57 \% \\
(0.6523)\end{array}$ & $\begin{array}{l}20.14 \% \\
(0.0000)\end{array}$ \\
\hline $\begin{array}{l}\text { Values of the first } \\
\text { derivate of the hazard rate }\end{array}$ & "less connected" managers & $\begin{array}{c}0.0056 \\
(0.5490)\end{array}$ & $\begin{array}{c}0.0091 \\
(0.6521)\end{array}$ & $\begin{array}{l}-0.0029 \\
(0.9162)\end{array}$ \\
\hline $\begin{array}{l}\left(-\partial^{2} \log (S) / \partial^{2} T\right. \\
\text { See eq. } 2)\end{array}$ & "more connected" managers & $\begin{array}{c}0.0044 \\
(0.6411)\end{array}$ & $\begin{array}{l}0.0083 \\
(0.6820)\end{array}$ & $\begin{array}{c}0.0160 \\
(0.5661)\end{array}$ \\
\hline
\end{tabular}

Table 10. Connections of the top managers as a whole and bank performance and survival. Variables referring to the top managers have been computed as averages over the past three years. All regressions use only one observation per bank at each point in time. Columns (1) and (2) report bank Fixed Effect estimates of performance on a set of variables including characteristics of the bank and time controls. Columns (3) and (4) report Fixed Effect (or Conditional) Logit estimates of the indicator "Bank not observed at time t" on a set of variables including characteristics of the bank, performance as well as time controls. A local manager is defined by distance $=0$. Robust standard errors in brackets; *** $\mathrm{p}<0.01, * * \mathrm{p}<0.05, * \mathrm{p}<0.1$.

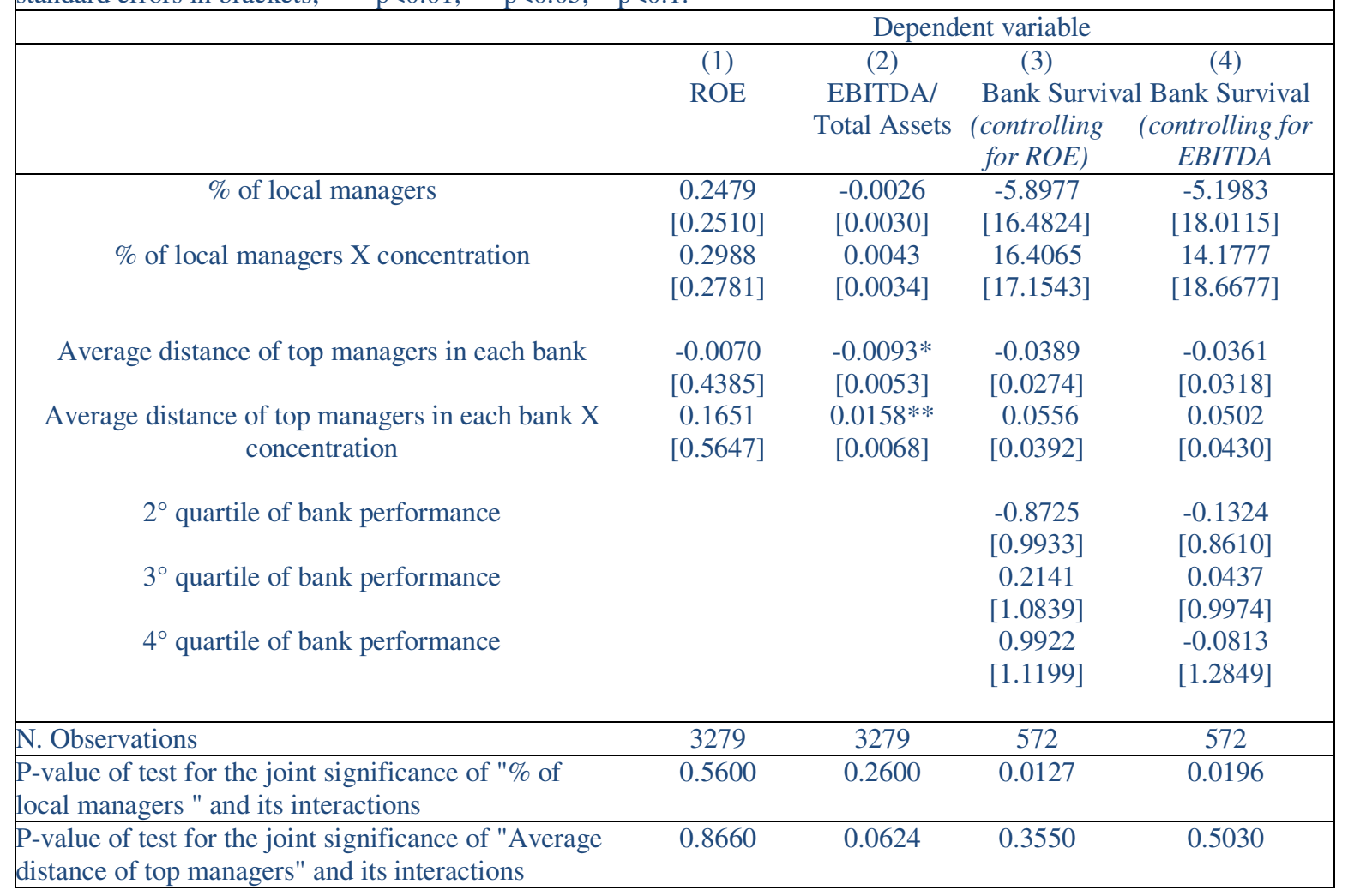


Table 11. Connections of the top managers and bank performance. All columns report Fixed Effect (FE) estimates of bank performance (ROE, EBITDA/Total Assets) on a set of variables including characteristics of the bank, characteristics of the manager and time controls. Results in column (1) and (3) account for bank FE only, while results in column (2) and (4) controls also manager for manager FE using data for "movers". A local manager is defined by distance $=0$. Robust standard errors in brackets $* * * \mathrm{p}<0.01, * * \mathrm{p}<0.05, * \mathrm{p}<0.1$.

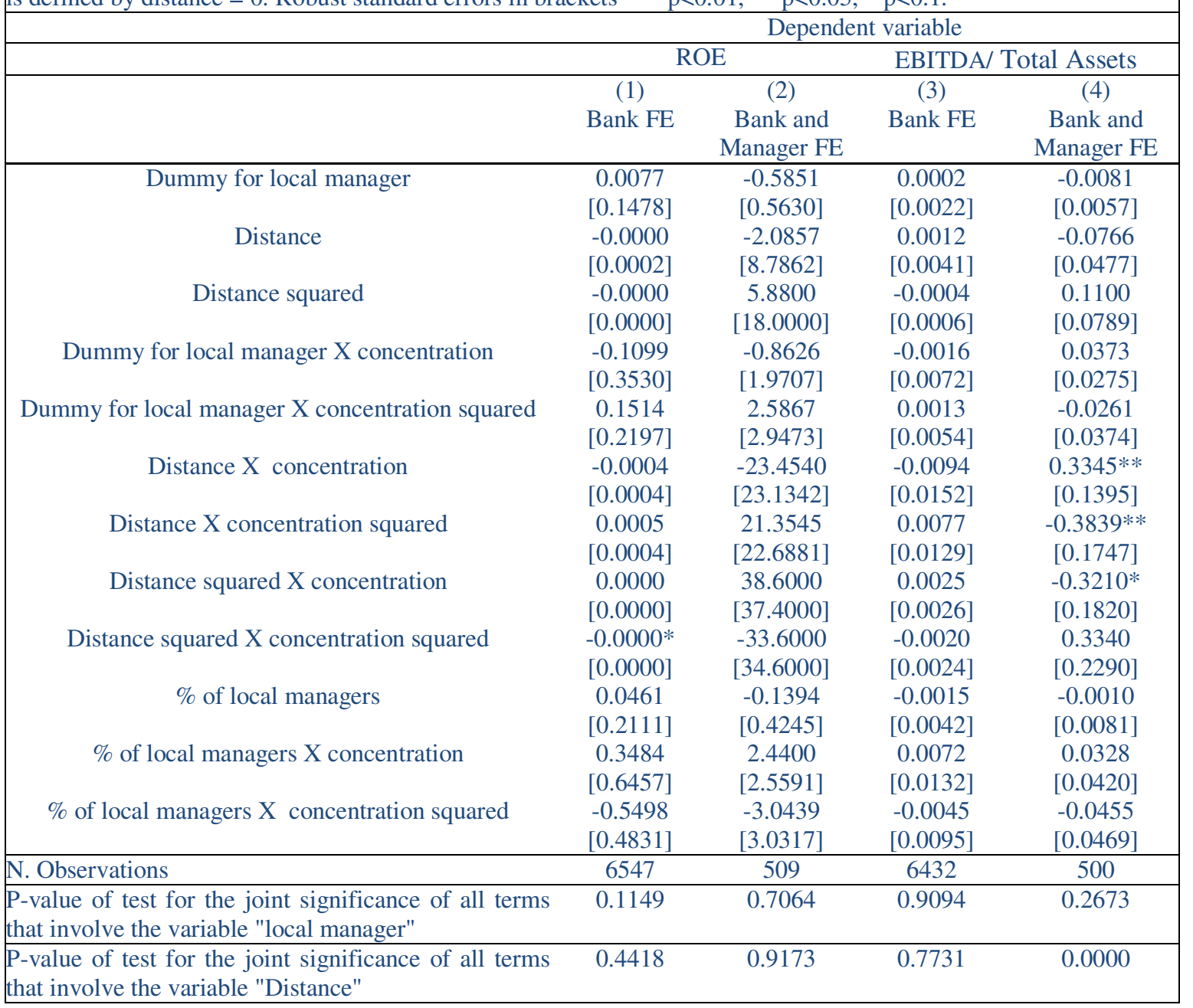




\section{CESifo Working Paper Series}

for full list see www.cesifo-group.org/wp

(address: Poschingerstr. 5, 81679 Munich, Germany, office@cesifo.de)

2377 Inmaculada Martínez-Zarzoso, The Impact of Urbanization on $\mathrm{CO}_{2}$ Emissions: Evidence from Developing Countries, August 2008

2378 Brian Roberson and Dmitriy Kvasov, The Non-Constant-Sum Colonel Blotto Game, August 2008

2379 Ian Dew-Becker, How Much Sunlight Does it Take to Disinfect a Boardroom? A Short History of Executive Compensation Regulation, August 2008

2380 Cécile Aubert, Oliver Falck and Stephan Heblich, Subsidizing National Champions: An Evolutionary Perspective, August 2008

2381 Sebastian Buhai, Miguel Portela, Coen Teulings and Aico van Vuuren, Returns to Tenure or Seniority?, August 2008

2382 Erkki Koskela and Jan König, Flexible Outsourcing, Profit Sharing and Equilibrium Unemployment, August 2008

2383 Torberg Falch and Justina AV Fischer, Does a Generous Welfare State Crowd out Student Achievement? Panel Data Evidence from International Student Tests, September 2008

2384 Pedro Gomes and François Pouget, Corporate Tax Competition and the Decline of Public Investment, September 2008

2385 Marko Koethenbuerger, How Do Local Governments Decide on Public Policy in Fiscal Federalism? Tax vs. Expenditure Optimization, September 2008

2386 Ronald McKinnon and Gunther Schnabl, China's Exchange Rate Impasse and the Weak U.S. Dollar, September 2008

2387 Yan-Leung Cheung, Yin-Wong Cheung and Alan T.K. Wan, A High-Low Model of Daily Stock Price Ranges, September 2008

2388 Louis Eeckhoudt and Harris Schlesinger, Changes in Risk and the Demand for Saving, September 2008

2389 Carsten Hefeker and Blandine Zimmer, Uncertainty and Fiscal Policy in an Asymmetric Monetary Union, September 2008

2390 Jay Pil Choi and Byung-Cheol Kim, Net Neutrality and Investment Incentives, September 2008

2391 Marcel Gérard, Financing Bologna, the Internationally Mobile Students in European Higher Education, September 2008 
2392 Annette Alstadsæter and Knut Reidar Wangen, Corporations' Choice of Tax Regime when Transition Costs are Small and Income Shifting Potential is Large, September 2008

2393 António Afonso and Christophe Rault, 3-Step Analysis of Public Finances Sustainability: the Case of the European Union, September 2008

2394 Betsey Stevenson and Justin Wolfers, Economic Growth and Subjective Well-Being: Reassessing the Easterlin Paradox, September 2008

2395 Bernhard Eckwert and Itzhak Zilcha, Private Investment in Higher Education: Comparing Alternative Funding Schemes, September 2008

2396 Øystein Foros, Hans Jarle Kind and Jan Yngve Sand, Slotting Allowances and Manufacturers' Retail Sales Effort, September 2008

2397 Mohammad Reza Farzanegan, Illegal Trade in the Iranian Economy: Evidence from a Structural Model, September 2008

2398 Olivier Bos, Charity Auctions for the Happy Few, September 2008

2399 Robert S. Chirinko and Debdulal Mallick, The Marginal Product of Capital: A Persistent International Puzzle, September 2008

2400 Ben D'Exelle and Arno Riedl, Elite Capture, Political Voice and Exclusion from Aid: An Experimental Study, September 2008

2401 Torben M. Andersen and Joydeep Bhattacharya, On Myopia as Rationale for Social Security, September 2008

2402 Fabienne Llense, French CEO Compensations: What is the Cost of a Mandatory Upper Limit?, September 2008

2403 Valentina Bosetti, Carlo Carraro, Alessandra Sgobbi and Massimo Tavoni, Delayed Action and Uncertain Targets. How Much Will Climate Policy Cost?, September 2008

2404 Robert G. Chambers, Rolf Färe, Shawna Grosskopf and Michael Vardanyan, Generalized Quadratic Revenue Functions, September 2008

2405 Leonidas Enrique de la Rosa, Overconfidence in a Career-Concerns Setting, September 2008

2406 Marcus Drometer and Johannes Rincke, The Design of Political Institutions: Electoral Competition and the Choice of Ballot Access Restrictions in the United States, September 2008

2407 Markku Lanne and Helmut Lütkepohl, Stock Prices and Economic Fluctuations: A Markov Switching Structural Vector Autoregressive Analysis, September 2008 
2408 Thomas L. Brewer, International Energy Technology Transfers for Climate Change Mitigations, September 2008

2409 Alexander Kemnitz, Native Welfare Losses from High Skilled Immigration, September 2008

2410 Xavier Vives, Strategic Supply Function Competition with Private Information, September 2008

2411 Fabio Padovano and Roberto Ricciuti, The Political Competition-Economic Performance Puzzle: Evidence from the OECD Countries and the Italian Regions, September 2008

2412 Joan Costa-Font and Mireia Jofre-Bonet, Body Image and Food Disorders: Evidence from a Sample of European Women, September 2008

2413 Thorsten Upmann, Labour Unions - To Unite or to Separate?, October 2008

2414 Sascha O. Becker and Ludger Woessmann, Luther and the Girls: Religious Denomination and the Female Education Gap in $19^{\text {th }}$ Century Prussia, October 2008

2415 Florian Englmaier and Stephen Leider, Contractual and Organizational Structure with Reciprocal Agents, October 2008

2416 Vittorio Daniele and Ugo Marani, Organized Crime and Foreign Direct Investment: The Italian Case, October 2008

2417 Valentina Bosetti, Carlo Carraro, Alessandra Sgobbi and Massimo Tavoni, Modelling Economic Impacts of Alternative International Climate Policy Architectures. A Quantitative and Comparative Assessment of Architectures for Agreement, October 2008

2418 Paul De Grauwe, Animal Spirits and Monetary Policy, October 2008

2419 Guglielmo Maria Caporale, Christophe Rault, Robert Sova and Anamaria Sova, On the Bilateral Trade Effects of Free Trade Agreements between the EU-15 and the CEEC-4 Countries, October 2008

2420 Yin-Wong Cheung and Daniel Friedman, Speculative Attacks: A Laboratory Study in Continuous Time, October 2008

2421 Kamila Fialová and Ondřej Schneider, Labour Market Institutions and their Effect on Labour Market Performance in the New EU Member Countries, October 2008

2422 Alexander Ludwig and Michael Reiter, Sharing Demographic Risk - Who is Afraid of the Baby Bust?, October 2008

2423 Doina Maria Radulescu and Michael Stimmelmayr, The Welfare Loss from Differential Taxation of Sectors in Germany, October 2008 
2424 Nikolaus Wolf, Was Germany ever United? Evidence from Intra- and International Trade 1885 - 1933, October 2008

2425 Bruno S. Frey, David A. Savage and Benno Torgler, Noblesse Oblige? Determinants of Survival in a Life and Death Situation, October 2008

2426 Giovanni Facchini, Peri Silva and Gerald Willmann, The Customs Union Issue: Why do we Observe so few of them?, October 2008

2427 Wido Geis, Silke Uebelmesser and Martin Werding, Why go to France or Germany, if you could as well go to the UK or the US? Selective Features of Immigration to four major OECD Countries, October 2008

2428 Geeta Kingdon and Francis Teal, Teacher Unions, Teacher Pay and Student Performance in India: A Pupil Fixed Effects Approach, October 2008

2429 Andreas Haufler and Marco Runkel, Firms' Financial Choices and Thin Capitalization Rules under Corporate Tax Competition, October 2008

2430 Matz Dahlberg, Heléne Lundqvist and Eva Mörk, Intergovernmental Grants and Bureaucratic Power, October 2008

2431 Alfons J. Weichenrieder and Tina Klautke, Taxes and the Efficiency Costs of Capital Distortions, October 2008

2432 Andreas Knabe and Ronnie Schöb, Minimum Wage Incidence: The Case for Germany, October 2008

2433 Kurt R. Brekke and Odd Rune Straume, Pharmaceutical Patents: Incentives for R\&D or Marketing?, October 2008

2434 Scott Alan Carson, Geography, Insolation, and Institutional Change in $19^{\text {th }}$ Century African-American and White Stature in Southern States, October 2008

2435 Emilia Del Bono and Daniela Vuri, Job Mobility and the Gender Wage Gap in Italy, October 2008

2436 Marco Angrisani, Antonio Guarino, Steffen Huck and Nathan Larson, No-Trade in the Laboratory, October 2008

2437 Josse Delfgaauw and Robert Dur, Managerial Talent, Motivation, and Self-Selection into Public Management, October 2008

2438 Christian Bauer and Wolfgang Buchholz, How Changing Prudence and Risk Aversion Affect Optimal Saving, October 2008

2439 Erich Battistin, Clara Graziano and Bruno Parigi, Connections and Performance in Bankers' Turnover: Better Wed over the Mixen than over the Moor, October 2008 